\title{
Development Environments and Factors of Subsidence Dolines
}

\author{
Márton Veress
}

check for

updates

Citation: Veress, M. Development Environments and Factors of Subsidence Dolines. Geosciences 2021, 11, 513. https://doi.org/10.3390/ geosciences11120513

Academic Editors: Charles Danquigny, Olivier Kaufmann, Caroline Lessio Cazarin,

Patricia Kambesis and Jesus Martinez-Frias

Received: 21 September 2021 Accepted: 9 December 2021 Published: 14 December 2021

Publisher's Note: MDPI stays neutral with regard to jurisdictional claims in published maps and institutional affiliations.
Department of Geography, Eötvös Lóránd University, Savaria University Centre, 9700 Szombathely, Hungary; veress.marton@sek.elte.hu

\begin{abstract}
This study describes the development environments of subsidence dolines based on literary data (development environments create favorable conditions for the local denudation of superficial deposit and thus, for the development of depressions). Development environments are the inclination of the bearing surface, the secondary porosity of the bedrock, the characteristics of the cover, water influx into the cover, karstwater and groundwater, melting permafrost, and anthropogenic activity. These may become optimal when controlled by various geological, geomorphological, and climatic factors. Development environments may be qualitative (there is doline development in case of its presence) and quantitative (doline development occurs in case of suitable quantitative values). The development environment groups of subsidence dolines are environment groups independent of water level, environment groups dependent on water level, and anthropogenic environment groups. In the case of an environment group independent of water level, surface morphology, cover characteristics, geomorphic evolution, and water supply are determining, while in case of an environment group dependent of water level, subsurface water level and its fluctuations and the characteristics of rainfalls interrupting dry seasons are crucial. Anthropogenic impacts mainly affect doline development through water balance.
\end{abstract}

Keywords: subsidence doline; karst; development environment interval; geohazard

\section{Introduction}

The aim of this study is to take into consideration development environments, effects, and their varieties, which result in the development of subsidence dolines and their varieties. On covered karsts, the frequent and rapid development of subsidence dolines result in the striking change of surface conditions and this process may cause a significant damage to man-made constructions. According to current scientific knowledge, a prediction on the development of subsidence dolines and their development sites, by which the damage could be reduced to a great extent, is not possible yet. Based on literary data, in this study, development environments and impacts are described that affect subsidence doline development and the site of development. Point of views are suggested for predicting the development and development sites.

Development environments and effects are described in various chapters. Development environments are the following: bedrock and cover characteristics as well as climatological and hydrological conditions, and anthropogenic impacts. Effects are surface inclination and porosity. In case of superficial deposits the role of thickness, grain size and calcareous content are analyzed in subchapters. The role of water is also described in subchapters (water inlet at rock boundary, water inlet at surface features). Subsidence dolines, which are also termed sinkholes in international literature [1,2], develop with surface subsidence as a result of the material loss of the cover.

Apart from karren, the most widespread landforms of karsts are dolines. Its types include solution dolines, collapse dolines, caprock dolines (caprock-collapse sinkholes), and subsidence dolines [1,3-6]. Solution dolines and collapse dolines develop on bare karst and/or soil-covered karst, while caprock dolines and subsidence dolines are formed on covered karst or interstratal karst [4,7]. According to Waltham and Fookes [8], subsidence 
dolines are dropout dolines (cover-collapse sinkholes), suffosion dolines, and compaction dolines. According to a newer classification of subsidence dolines $[1,2,6,9]$, in addition to collapse dolines (among which cover collapse sinkholes and caprock collapse sinkholes are distinguished based on cover quality) sagging sinkholes (with cover sagging and caprock sagging variety based on cover quality) are described. Sagging sinkholes develop by the sinking of the cover. Cover sinkings, which also occur at suffosion (see below), are primarily specific of evaporites $[2,10]$.

Subsidence dolines develop on concealed karst, which is a variety of covered karst (the cover is unconsolidated, non-cohesive, but it may also be partly cohesive or completely cohesive, permeable, but impermeable to various degree too) [11]. Concealed karst develops where the cover is young (moraine, loess, alluvium), the denudation of the surface is impeded (karstic depression, dry valleys), or continuous development of weathering residue (tropical karst) occurs [11-13]. Concealed karsts are widespread on Earth for example on glaciokarsts [14], on tropical karsts [15,16], on permafrost [17], and on coastal karsts [18]. In addition to carbonate karsts, it can also develop on evaporite karsts if they are covered by unconsolidated cover [1,6,19-25].

Concealed karst mostly occurs with other karst types alternately. Its study has a practical significance $[1,6,26,27]$ since its rapidly developing features endanger man-made constructions (roads, railways, buildings, etc.).

On concealed karst, the cover is loess (and its clayey varieties), sand, and rarely clay. On sites of intensive karstification, the cover is weathering residue such as on tropical karsts $[8,28]$. On glaciokarsts, it is frost weathering debris of bedrock origin and moraine $[3,29]$.

Subsidence dolines develop during the material rearrangement and material loss of the cover at sites where secondary porosity is great or increases on the bedrock by which some part of the cover is locally transported into the bedrock. Material reception sites may be the depressions of the bedrock surface (karren), the cavities of the epikarst, the epiphreatic and the phreatic zone as well as the passages and cavities of the cover [18,29-31]. The most common sediment receptor is the epikarst due to its close position to the surface and great secondary porosity. According to Williams [32], the secondary porosity of the epikarst may reach $30 \%$ too.

Material from the cover may get into the bedrock through slow and fast (collapse) material transport. In the latter case if it loses its stability and dropout dolines are formed. The stability of the cover depends on the cover thickness, on the size of cover cavities, on the flow velocity of groundwater, on the pressure of the pore water [33], and on water extraction, but it is also affected by construction works and vehicle traffic [29], by pointlike increased load [34]. Loading and vibration triggered by vehicle traffic results in the breakdown of cavities and contribute to the development of dropout dolines (Yuan 1987). Earthquakes may cause cavity collapses [1,35]. Such an event occurred by blasts in China [36]. In Croatia, earthquakes starting at the end of December 2020 resulted in the development of about 100 dropout dolines near Mečenčani and Borojeviči [37]. Here, the development of several dolines coincided with the day of shocks. In the above mentioned cases, the cover loses its stability when the value of one (or several) of the above-mentioned characteristics exceeds a certain degree. This can be regarded as a crucial value for doline development. Material loss from the cover can be dissolution (therefore, in case of calcareous cover, the water may reach the bedrock in saturated state), suffosion [3,4,29], solifluction [8,38,39], collapse [4,29], and grain fall [11]. According to model experiments [40], the material rearrangement in the cover can be vertical and with horizontal suffosion, which is followed by compaction. Material rearrangement in the cover may happen by the collapse of the cavities of the cover [29,31], and/or by the detachment of particles from the cover ceiling if the pressure of pore water increase in the cover [41], or if the water level decreases in the cover and in its cavity and this results in the increase of hydrostatic pressure, which causes the failure and thus, the collapse of the material above the cavity of the cover $[31,41,42]$. Material transport in the cover may be reworked 
and transported into the bedrock. Measurements have shown that a drop of groundwater level may trigger cavity development (with the collapse of the latter, doline development) without the water level sinking below the surface of the bedrock [31]. It probably occurs when material is reworked from the lower part of the cover into the karstic rock and thus, porosity increases. In this case, water motion associated with decreasing water level (independently of meteoric water) transports material downward from the upper part of the cover. However, when there is no groundwater in the cover, the infiltrating waters cause material transport by suffosion. The above processes result in the local thinning of the cover and in surface subsidence above these sites and thus, in the development of subsidence dolines.

On permeable cover, subsidence doline varieties are suffosion dolines (their side slopes are of various gradient), on partly impermeable cover, their varieties are dropout dolines (steep with vertical sides) and compaction dolines (with gentle slopes) [4,8,29]. Based on the order of the above list, the main processes are suffosion and grain fall, collapse and compaction. Frequently, several processes have a joint effect. Thus, compaction [43], or the collapse of the cavities of the cover [44] is preceded by suffosion.

Suffosion takes place at loose (non-cohesive), permeable cover. Geophysical measurements refer to the fact that suffosion begins at the lower part of the cover preceding the local subsidence of the cover. At the bottom pipes and inclined sediment structures develop (Figure 1, [45]), and porosity increase occurs in stripes which stripes develop towards the surface [46]. The upward spreading material loss causes the thinning and/or warping of the upper beds, which results in the subsidence of the surface [47]. Collapse primarily takes place by the collapse of the cover cavities [29,31] when a dropout doline develops. However, it may also happen by the collapse of the bedrock cavities. This occurs when the material shortage of the bedrock is great and develops fast. In this case, the collapse also spreads onto the cover or the collapse first creates a cavity on the cover and then this cavity collapses [7]. Thus, for example, above breccia pipes [8], above passages that were formed on the ceiling of horizontal caves [7], or above horizontally mature cavities [22,29,30,48]. In this latter case, dropout dolines show similarities with caprock dolines. However, at caprock dolines, the consolidated rock collapses into the cavity of the bedrock [8]. It is probable that there is a strong relation among the collapse causing the development of dropout dolines, the cohesiveness of the cover and the diameter of the bedrock passage. The less cohesive the cover, the smaller bedrock passage diameter can develop cavities by suffosion, though, their size is small, thus, the size of the developing dropout doline will also be small. However, dropout dolines can also be formed if the size of the bedrock cavity is large and the cover is non-cohesive such as in the environs of Konya in Turkey [7]. The more cohesive the cover, the less probable the occurrence of suffosion. In the cover, collapse is necessary for cavity development, a precondition of which is that collapse should also take place on the bedrock. This may result in the development of a large-sized cavity in the cover, thus, the dropout doline will be larger too. Grain fall occurs if the cover is non-cohesive or if it is cohesive, but the pressure of pore water is large in it and the bedrock passages are relatively large. 


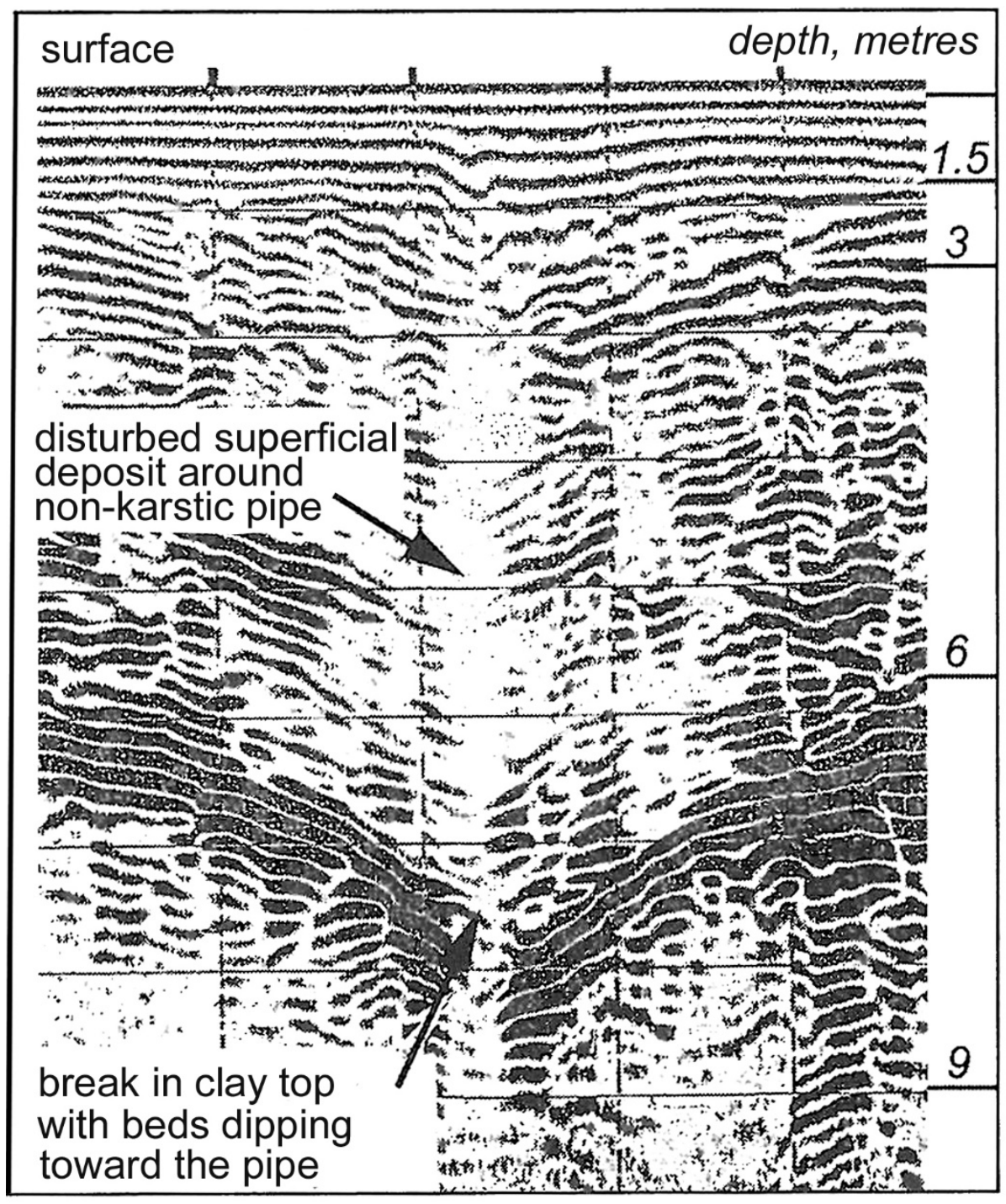

Figure 1. An image from ground probing radar that could not reach below clay [45] (modified).

A precondition of the above-mentioned processes is (even in the case of material reworking within the cover) that the bedrock should have material recipient capacity, thus, secondary porosity. This is possible if during its karstification cavities opening onto its surface (caves, shafts, pits, and passages), karren develop [3,4,29,44,48]. The position and shape of the cavities is significant: if they are close to the bedrock surface and horizontally developed, there is a greater chance for the development of subsidence dolines [30].

On covered karst features with a large diameter (it can exceed $100 \mathrm{~m}$ ) and small depth can develop on superficial deposit, which are depressions of superficial deposit [11]. Their development takes place through the local denudation of the surface mainly by pluvial erosion since the material of the cover is transported into the karst through the earlier formed subsidence dolines (occasionally through ponors).

Subsidence dolines are often regarded as ponors if a water drainage feature (valley, channel) is connected to them. However, they are not ponors genetically, but depressions functioning as ponors since they are not depressions with blind valleys that developed at rock boundary, which is a characteristic of ponors [5,49]. On the contrary, subsidence dolines can develop independently of rock boundary, where the karst has a material receiving capacity and the cover is impermeable. Veress [11] described depressions functioning as ponors developing in the area of superficial deposit as covered karst ponors. In Florida where limestone is situated close to covered karst surfaces, depressions termed swallets 
develop in the non-karstic cover in the valleys of watercourses [18]. These can be regarded as subsidence dolines with permanent water recipient capacity.

On calciferous, unconsolidated rocks, depressions can be formed (pseudokarstic depression) on loess and calciferous conglomerate during the dissolution of limestone without karstifying limestone bedrock too [49-53]. Some depressions on the calciferous moraine of glaciokarsts are probably of such genetics.

Subsidence dolines can be syngenetic and postgenetic [11,46]. In case of syngenetic dolines, the development age of material recipient bedrock features and of the depressions developing on the cover is the same, actually the occurrence of the two phenomena mutually presuppose each other [54]. In case of postgenetic subsidence dolines, these features of the bedrock are older (they may be even older than the accumulation of the superficial deposit). Depressions developing only by the compaction of the cover are neither syngenetic nor postgenetic. Sediments with lenticular development refer to postgenetic depressions, which developed during the infilling of older depressions situated below present depressions $[11,46]$. The chance of the development of postgenetic depressions is great on calciferous thick cover since the water percolating through it may become saturated before reaching the bedrock [55-57]. The bedrock cannot be solved under such cover, thus, the sediment recipient feature is older than the cover. The depression is also postgenetic in case of limestone cover (moraine of glaciokarsts) even if it is thinner and the saturation level is above the bedrock surface.

Postgenetic depression development also occurs at sites where depressions are formed within a short time after intensive rainfalls since sediment recipient features cannot develop (simultaneously at several sites) below the cover in the bedrock within some days. The greater the doline density, the more likely it is that dolines are postgenetic though on evaporates some of them may be syngenetic even at great density. The rate of postgenetic doline development is also significant because of the already existing sediment recipient features below the cover. In Florida, a newer doline is formed weekly [58]. Its development rate is 0.055 doline $/ \mathrm{km}^{2} /$ year [29]. A greater rate is specific of the area of the Western Pennyroyal karst of Kentucky where the development rate of dropout dolines was 0.2 dropout doline $\mathrm{km}^{-2}$ year ${ }^{-1}$ between 1971 and 1991 [41]. A minimal rate of 0.11 doline $\mathrm{km}^{-2}$ year $^{-1}$ was reported from Florida by Beck [59] and 0.04-0.64 doline $\mathrm{km}^{-2}$ year $^{-1}$ from Eastern Tennessee by [60]. The higher the development rate, the more likely it is that the developing dolines are postgenetic.

In depressions, lakes (permanent lakes with stabile water level and intermittent lakes with changing water level), while in filled or partly filled subsidence dolines, marshy, waterlogged patches may develop. The filling of the depression with impermeable sediment, the clogging of the depression passage, and the fluctuation of the groundwater and/or karstwater level play a role in their development $[18,29,58]$. It may occur that the lakes develop not only above one, but above several subsidence dolines [18]. In this case, the water of the lake is also present in the terrain between the dolines.

\section{Spatial Patterns of Subsidence Dolines}

According to observations and the spatial analysis of karst morphological maps [11], the pattern of subsidence dolines is local (Figure 2B), aligned in rows (Figure 2A), and areal (Figure 2D). 

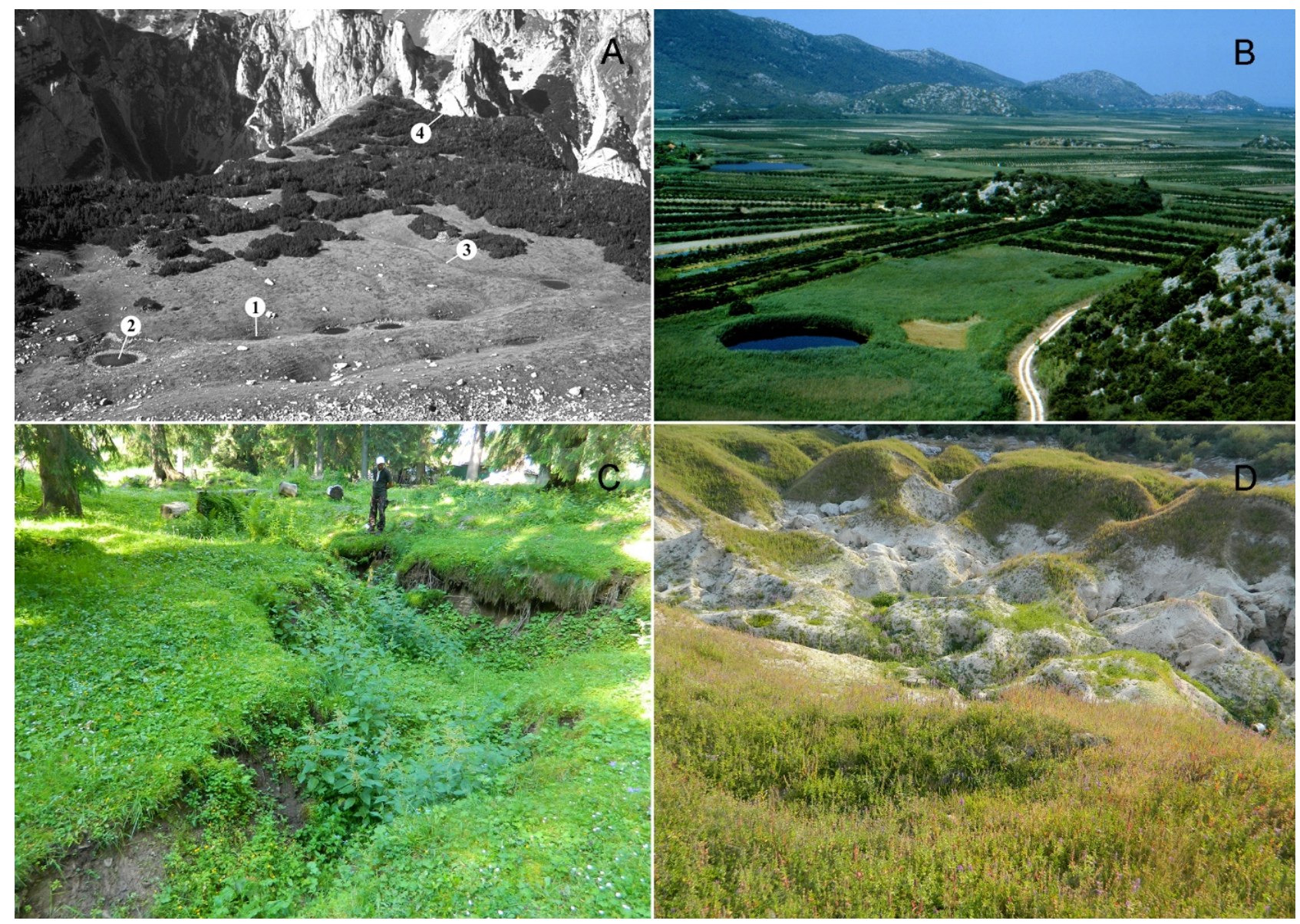

Figure 2. Subsidence dolines. (A) subsidence dolines that developed along fracture (Durmitor), 1. active doline, 2. inactive doline with lake, 3. path of water inflow, 4. Susica Canyon. (B) Dropout doline with lake in the Neretva river's mouth (Croatia). (C) Subsidence doline that developed along fissure (Pádis, Romania). (D) subsidence dolines that developed in depressions of superficial deposit of a polje (Croatia).

\subsection{Local Pattern}

In case of local pattern, the arrangement of the dolines is irregular as compared to each other and their distance from each other is large in every direction (they are several hundred meters away from each other, the distance of which is larger than their diameter with order of magnitude) Local pattern develops when the development environment forces the shaping factors to become local. Dolines of local pattern may be both syngenetic and postgenetic.

\subsection{Row Pattern}

In case of row pattern, the dolines are aligned in rows, they have a closer position to each other along the row (although their distance from each other exceeds their diameter, but not with an order of magnitude), the length of the row may be several hundred meters or kilometers as well. Row pattern may be linear or banded. When the pattern is linear, an arcuate or straight line can be fitted to the dolines (Figure 2A), and when they have a banded pattern, the distribution of the dolines can be determined by two tangential lines.

Row pattern is formed when sediment recipients with row pattern develop because of bedrock structure, or the shaping factors have an effect only in a narrow band due to the development environment. Dolines of linear pattern are syngenetic since there is a little chance of the occurrence of superficial deposit recipient features of various ages (thus, older too) on the bedrock in only one row. However, the more scattered the distribution of depressions, the greater the chance of the presence of old sediment recipient features 
(that developed preceding depression formation) on the bedrock. Therefore, as the width of doline band increases, the chance of the occurrence of postgenetic depressions within the band will also be greater.

\subsection{Areal Pattern}

Dolines with an areal pattern are widespread in two directions on the surface of the karst, they are situated close to each other. Although the distance between them may be larger than their diameter, but not with an order of magnitude. In case of such pattern, doline density is large. On the covered karst of Western Mecsek (Hungary), this density is 380 doline $/ \mathrm{km}^{2}$ [61]. On a section of Răchite uvala (Padis, Romania), the density is 5.94 doline $/ 100 \mathrm{~m}^{2}$, its value is 593.21 doline $/ \mathrm{km}^{2}$ when calculated to $1 \mathrm{~km}^{2}$ [11]. On gypsum karst (Ukraine), also including caprock dolines, the density is 200 doline $/ \mathrm{km}^{2}$ [22] In a given area, over a certain density, though its value is unknown, the pattern may be only areal. The threefold pattern may alternate on the karst, the areal pattern may be separated into shorter and longer doline rows.

Areal pattern develops when the development environment favors the activity of the shaping factors in broad expansion and large density (simultaneously or at different time) and when the pattern of the sediment recipients of the bedrock is also areal. Such a development environment may occur at evaporate bedrock, or on thin cover at carbonate bedrock with plain surface. In case of areal pattern, depressions may be formed simultaneously or almost simultaneously (for example during intensive rainfalls, to the effect of floods and earthquakes, due to anthropogenic activities such as mining, explosion, or natural or artificial karstwater level subsidence), or a at different time. Simultaneously developing depressions are postgenetic. In the case of depression development at various times, there is also a greater chance of syngenetic development when newer sediment recipients are formed on the bedrock. In the case of postgenetic depression development, when the development of depressions happened at various times, the shaping processes are of different time or intensity.

\section{Bedrock Factors (Variables) of Doline Development}

Since subsidence dolines are formed on karst covered with superficial deposit, the existence of covered karst (concealed karst) is a basis for the appearance of subsidence dolines. It has two preconditions: the development and survival of a suitable unconsolidated cover rock. Its development is determined by the elevation, dissectedness, and position of the karst. Thus, for example, European and North American loess developed in front of ice cover, while the loess of China was formed at desert sediment sources. Loess development also has an altitudinal limit. According to Mezősi [62], loess of Hungary developed on terrains with an elevation less than $400 \mathrm{~m}$ (although, according to observations, on Hungarian karsts this can be slightly exceeded by the altitude limit). Regarding Hungarian horsts, the larger the altitude of a horst, the less the chance of loess development, and the larger its relative elevation and the smaller its expansion, the smaller the chance of the survival of the loess, and thus, of the development of concealed karst [63]. Moraine develops at smaller and smaller parallels at larger and larger altitudes (however, at the same site is more and more transformed and more and more clayey with the decrease of altitude). Wind-blown sand develops under dry climate along rivers and at seaside. During fluvial transport, a sandy-hardly worked sandstone cover with debris is formed when sandstones occur adjacent to the karst (Pádis, Romania). At sites of intensive karstification (tropical climate, Mediterranean climate), the cover is weathering residue.

For doline development, the cover should survive permanently. This happens when the surface of the karst is less dissected, has a large expansion, and low elevation, particularly at sites where sediment traps (valleys, karstic depressions) occur.

Doline development environments and factors that play an indirect or direct role in the local denudation of the bedrock are the following:

- the inclination of the bearing surface, 
- the secondary porosity of the bedrock,

- the characteristics of the cover,

- water inlet into the cover,

- the presence of karstwater or groundwater,

- the melting permafrost,

- anthropogenic activity.

Development environments may have various qualities that are controlled by the distance compared to the base level of erosion, lithological conditions, geomorphological processes, and the climate.

\subsection{Inclination of the Bearing Surface}

The inclination of the surface is development environment because it affects the infiltration of surface waters, the pattern and size of the solution features on the bedrock, and the thickness of the cover. Regarding either solution dolines or subsidence dolines, for example, on the Western Mecsek Karst, doline development is the most intensive when the surface inclination is $2-4^{\circ}$ [64]. On surfaces with a dip larger than $13^{\circ}$ at the same site, where infiltration is probably of lower degree, there are no dolines at all [64].

According to model experiments [40], if the inclination of the bearing plaster plate is $0^{\circ}$ and the grain size of the superficial deposit is smaller than $0.063 \mathrm{~mm}$, dissolution is local. If the bedrock is inclined, dissolution is more widespread (smaller features develop in great density). If the inclination of the plaster plate is $5^{\circ}$, the passage is more elongated and a dissolution channel develops in its continuation on the plaster surface. According to investigations carried out on the Western Mecsek Karst under natural circumstances, the longer axis of the dolines coincides with the slope direction of the surface, and the larger the inclination, the more elongated the subsidence doline [65]. However, subsidence dolines elongated in slope direction are also widespread on other karsts [3]. The reason for the relation between elongatedness and dip direction is that percolation (and thus, dissolution) on the inclined bedrock and suffosion material transport from the cover are more expanded in dip direction [65]. However, the low inclination of the bearing surface (particularly if its expansion is large) also protects the thinly overlying cover against denudation, creating favorable conditions for subsidence doline development.

Low-inclined surfaces constitute concealed karst on abrasion platforms [66], for example on the Western Mecsek Karst, on block roofs [63,67] for example in the Bakony Region (Hungary), on river terraces [68] such as in the valley of the River Ebro (Spain), and on the glacial surfaces of former ice cover [3] like on the British Isles. However, karst features with plain floor may be of low inclination too and thus, have concealed karst surfaces such as the low-inclined floors of some dolines and uvalas of the temperate belt [11], depressions of cockpit karst [69], poljes [3], and of intermountain plains [29].

\subsection{Porosity of the Bedrock}

Fractures, faults, and bedding planes are sites of dissolution and thus, they have an indirect role in doline development. The greater the role of structure in doline development, the greater the chance of their linear pattern (Figure 2A). If there are tectonic fissures on the bedrock or breccia pipes on evaporate karsts, they are sediment recipients even without the dissolution of the bedrock. At tectonic fissures, sediment transportation into the karst is curtain-like, the developing dolines are postgenetic and their groundplan is furrow-like (Figure 2B).

The size (diameter, length) and pattern of the sediment recipient features of the karst (including the features of the bedrock surface), and their connection to the caves of the karst determines the development way, width, and size of depressions [11,22,29,48] (Figure 3). According to model experiments [70], a depression developed on the cover by artificial grain fall at any cover thickness (this was 5-30 cm during the experiment) and at any passage diameter (being $0.5-1.5 \mathrm{~cm}$ ) when a space with a minimum elevation of $2.5 \mathrm{~cm}$ was created below the bearing plaster plate. However, when the grain size was large 
(1-2 $\mathrm{mm})$ and the diameter of the pit was only $0.5 \mathrm{~cm}$, no depressions developed even in case of a space with an elevation of $2.5 \mathrm{~cm}$ since material fall did not start at all or it was blocked. In the lack of a space below the plaster plate, dolines only developed when the thickness of the cover was the smallest $(5 \mathrm{~cm})$ possible (the aim of these experiments was to make postgenetic depressions, since the passage in the plaster was created preceding the formation of the cover put on the plaster plate and thus, before the development of the depression). The results of the experiments also prove that it depends on the sediment recipient feature formed either on the bedrock or in the bedrock whether a doline develops and if it does what development rate and size it has.

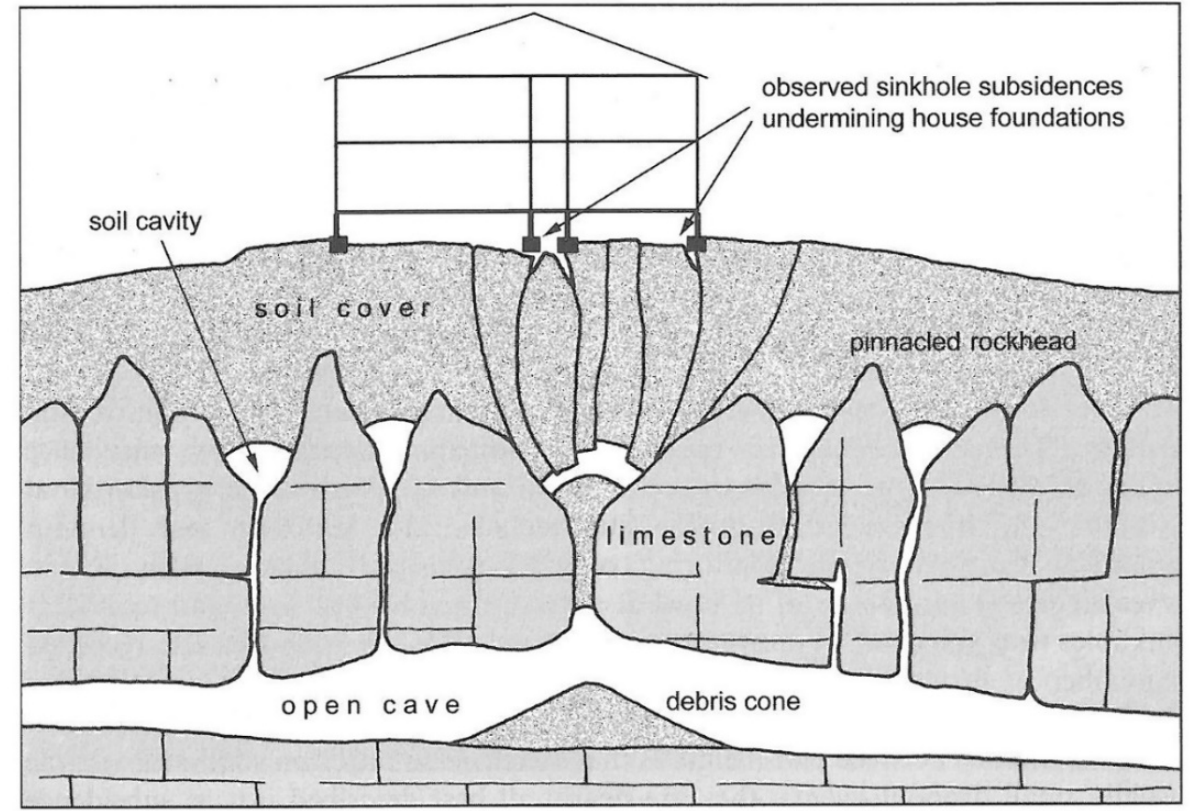

Figure 3. A model of subsidence dolines that developed above a cave and karren bedrock by cover collapses (Kentucky) [48].

A similar sediment recipient may be the depression of the bedrock if cavities are formed between the bedrock and the cover here (Figure 3, [48]). However, if the depressions of the bedrock are karren features, they represent well the relation between the size of the recipient space and the size of the doline. Thus, if the sediment recipients of the cover are karren, only small depressions develop since these features can only receive little material [71,72]. In addition to the young development age, this characteristic feature probably also contributes to the development of the dolines of glaciokarsts with small size, but large density because of the widespread distribution of karren [11]).

The sediment recipient features of the bedrock can also be inherited to the cover directly by collapse [73]. In case of inheritance, the collapse of the bedrock (when the passage develops towards the surface) is directly followed by the collapse of the cover and thus, by doline development [11]. Bedrock features resulting in such inheritance are breccia pipes $[19,74]$, tributary shafts branching out of main shafts (Figure 4, [11,18]), the sediment loss of plugged passages [75], and the horizontally developed cavities being close to the surface [30]. During the collapse of breccia pipes, it depends on the quality of the cover what type of doline (caprock, dropout, or suffosion) develops [22].

According to Veress [11], a large secondary shaft terminating towards the surface develops by the dissolutional coalescence of small primary shafts (pits or grikes) situated under the permeable cover in the bedrock. Its collapse can also be inherited onto the cover $[11,76]$. 


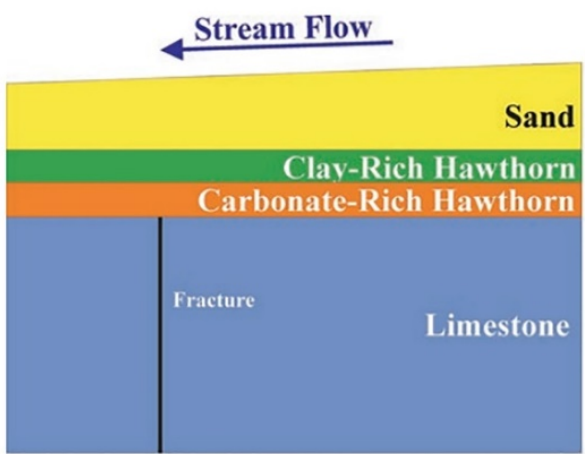

Time Step 1

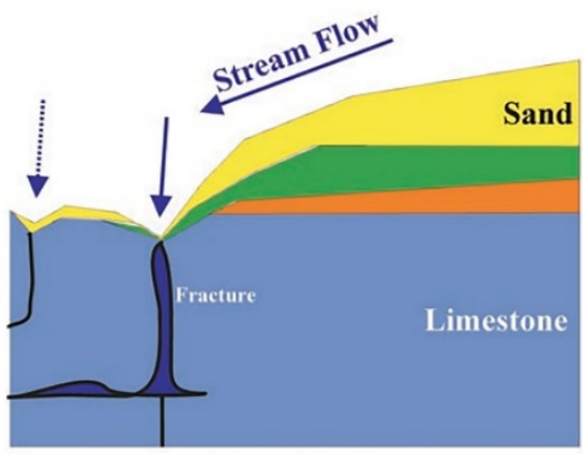

Time Step 3

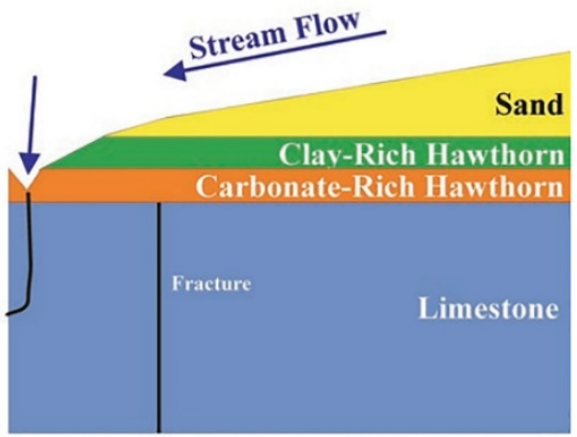

Time Step 2

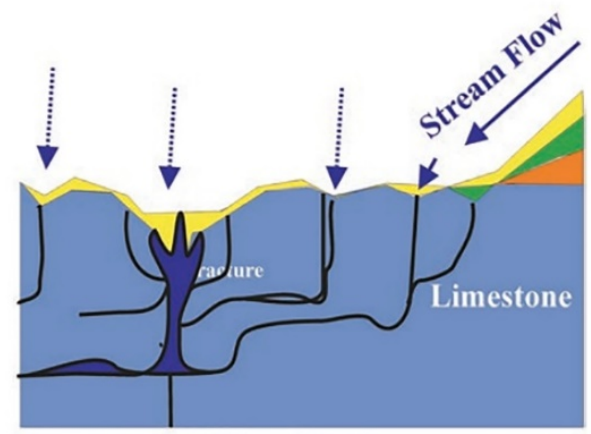

Time Step 4

Figure 4. Subsidence dolines above main passages and tributary passages [18].

\subsection{Characteristics of the Geological Cover}

The thickness, grain size, composition (impermeability, the quantity of calcareous content), the porosity, and the structure of the cover affects whether doline development takes place at a given site, and if it does, in what way it happens.

\subsubsection{Cover Thickness}

Cover thickness regulates the development, pattern, density, and size of the doline. According to [29], in thicker cover, smaller subsidence dolines develop (Hyatt et al.). The study [77] states that doline size is independent of cover thickness or permeability, but it depends on the type and age of the cover. Their development is also rather influenced by the type and structure of the cover [78]. However, according to experiments modelling the development of postgenetic depressions, there is a relation between cover thickness and the size of the doline that developed by grain fall [70]. Based on the results of grain fall model experiments, the smaller the thickness of the cover in case of the same grain diameter, the same diameter of the passage in plaster and the same space below it, the larger the depression in spite of the fact that the quantity of the material that leaves the cover does not increase. The material shortage state triggered by a cover of a given quantity spreads onto cover material having smaller and smaller thickness, thus, volume. As a result of this, when the same quantity of material leaves, it affects a larger proportion of the cover, which enables the development of a larger depression. Thus, during the above experiments, in case of a cover thickness of $20 \mathrm{~cm}, 42 \mathrm{~cm}^{3}$ material fell, and the volume of the depression was $0.1 \mathrm{~cm}^{3}$, while in case of a cover thickness of $5 \mathrm{~cm}, 44 \mathrm{~cm}^{3}$ material fell from the cover and the volume of the depression was $36.8 \mathrm{~cm}^{3}$ [70].

In China, $60 \%$ of investigated subsidence dolines was formed on a cover with a thickness smaller than $5 \mathrm{~m}[36,79]$. In Florida, most dolines developed on a cover thinner than $20 \mathrm{~m}$ [80], and thinner than $25 \mathrm{~m}$ [81]. Dolines rarely develop on thicker cover than these, and if they do, individual formation is specific. Thus, they developed on cover thicker than $70 \mathrm{~m}$ in China [82], on cover thicker than $85 \mathrm{~m}$ in Pádis (Romania) [83], on 
cover with a thickness of $150 \mathrm{~m}$ in Florida [84], and on cover of a thickness of $200 \mathrm{~m}$ in Italy [29]. In case of great cover thickness, doline development is influenced by water rising to the effect of geothermal heat [85]. It is probable that dropout dolines develop even in case of larger cover thickness. In Florida (Winter Park), such doline was formed at a 45-m thick cover [29]. In Florida, sulfuric acid water originating from gypsum bedrock results in hypogenic cavity development and the collapse of these cavities causes the development of dropout dolines [18].

Veress [46] investigated the thickness and composition of the cover at 43 subsidence (suffosion) dolines in the Bakony Region (Hungary) based on the data of VES measurements. Among syngenetic dolines, the cover is smaller than $3.5 \mathrm{~m}$ at 9 dolines, this value is $3.51-6.0 \mathrm{~m}$ at 11 dolines and larger than $6.01 \mathrm{~m}$ at 4 dolines at the margin of the depression. At postgenetic dolines, the cover was thinner than $3.5 \mathrm{~m}$ in case of 2 dolines, $3.51-6.0 \mathrm{~m}$ at 6 dolines, and larger than $6.01 \mathrm{~m}$ at 11 dolines at their margins.

According to Klimchouk and Andrejchuk [22], doline density decreases with the increase of cover thickness (Figure 5). However, the gradient of doline density curves is different in the function of cover thickness in three karst areas studied by them, which was explained by the various extent of cavity development of the gypsum, by the different structure and composition of the cover.

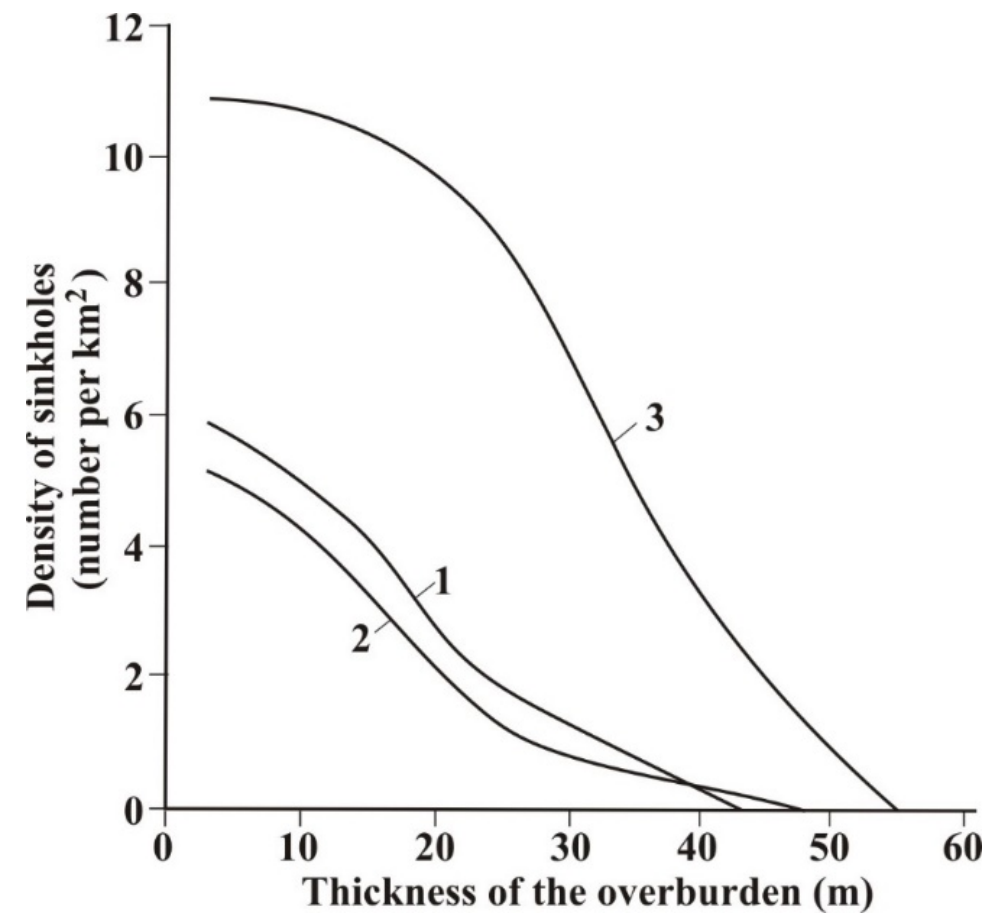

Figure 5. Relation between the number of subsidence dolines and cover thickness on Ukraine gypScheme 22 [23]. 1. in the Seret-Nichlava interfluve (entrenched karst), 2. in the Cerny Potok area (subjacent karst), 3. in the Zoloushka cave area (subjacent karst).

Cover thickness is affected by accumulation and denudation. A small cover thickness of accumulation origin develops during the formation of loess, moraine (ground moraine) and weathering residue. These accumulation environments, particularly if the bedrock has a plain surface, favor areal doline pattern development. However, the cover is also locally thin if the bedrock is uneven. In this case, the cover is locally thin above the mounds of the bedrock (Figures 6 and 7a). Subsidence (suffosion) dolines developing above the mounds have a local pattern or their pattern may be similar to the pattern of buried mounds and they can even constitute a row. A total of 31 dolines out of 43 dolines studied by VES measurements in the Bakony Region are above the buried mounds of the bedrock $[46,63]$. 


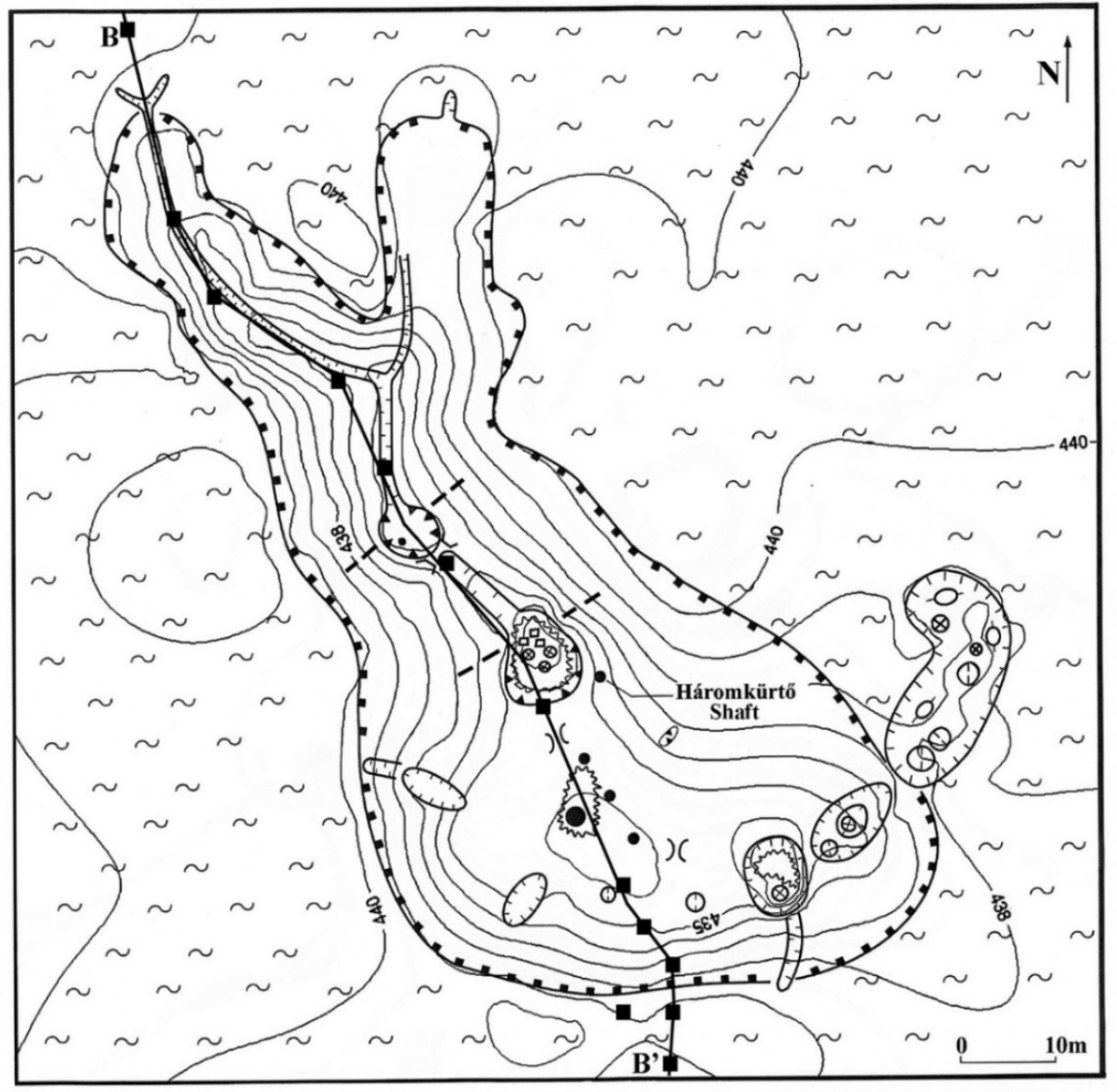

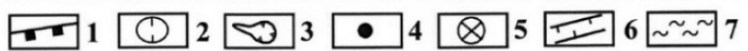

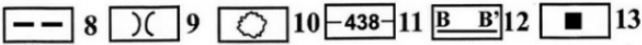

a

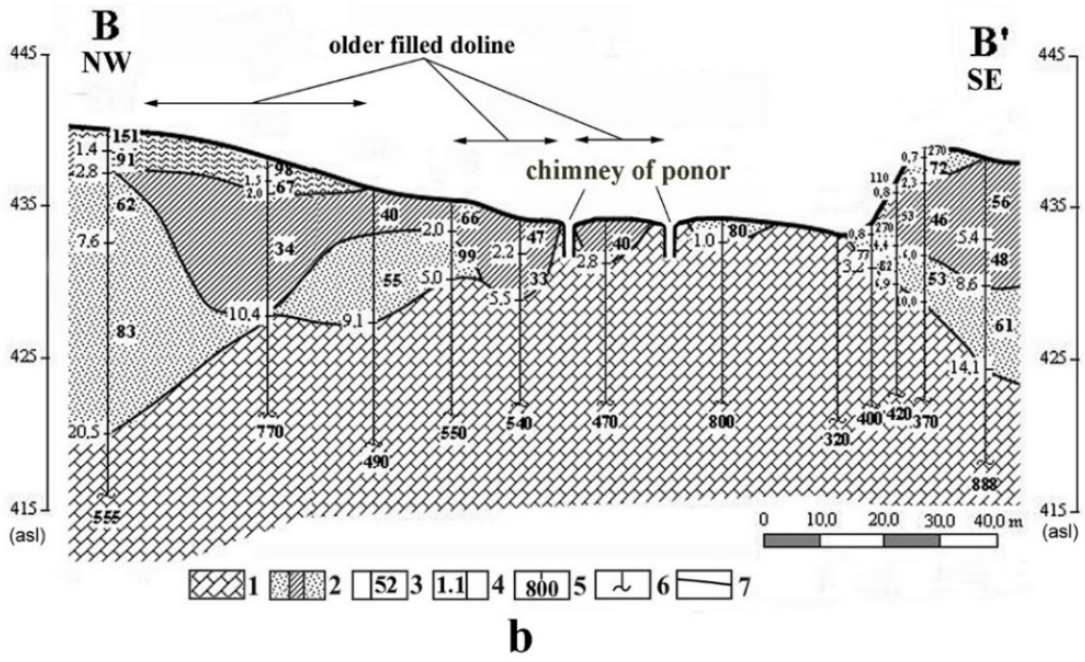

Figure 6. Depression bearing Háromkürtó shaft (a) (Tés Plateau, Hungary) and cover thickness condition in its environs (b) ([11] modified). Legend: (a) 1. margin of DSD, 2. subsidence doline, 3. ponor, 4. pit, shaft, 5. passage in the cover, 6. creek, 7. surrounding terrain, 8. rock boundary, 9. saddle, 10. rock outcrop, 11. contour line, 12. track of profile, 13. VES measurement site, (b) 1. limestone, 2. superficial deposits of various grain, 3. geoelectric resistivity of series (Ohmm), 4. base depth of geoelectric series (m), 5 . geoelectric resistivity of bedrock (Ohmm), 6. approximate penetration depth of VES measurement, 7. boundary of geoelectric series. 


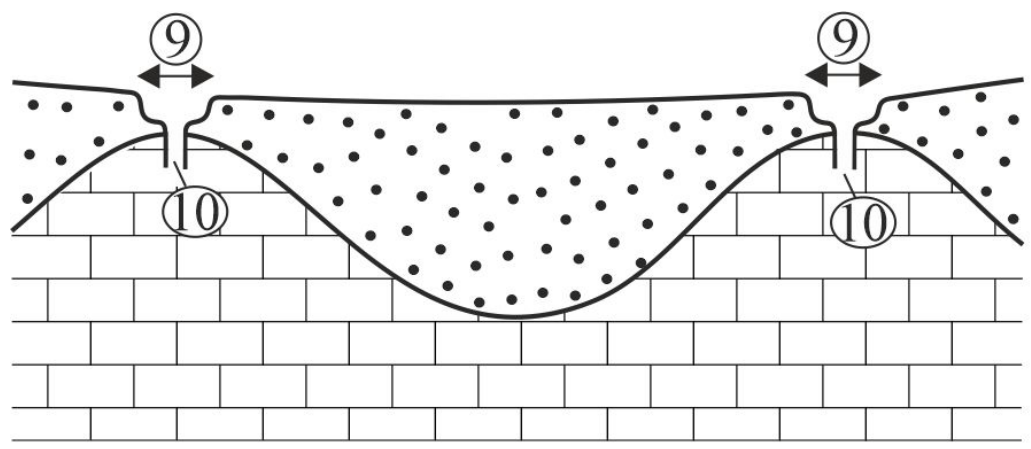

a

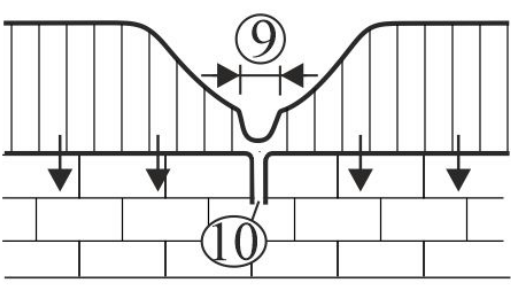

$\mathrm{c}$

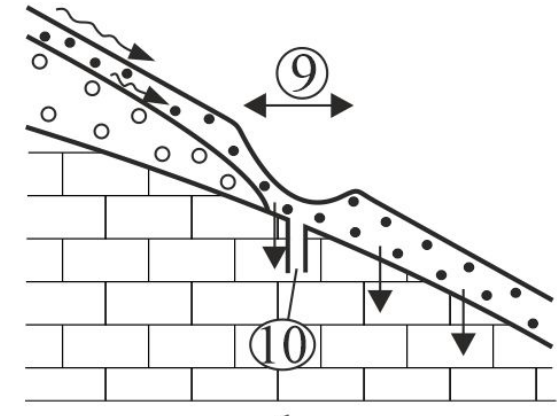

d

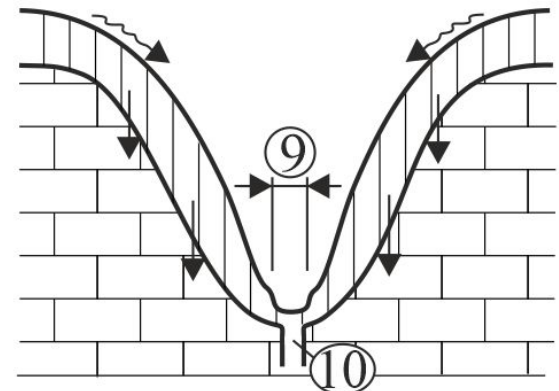

b

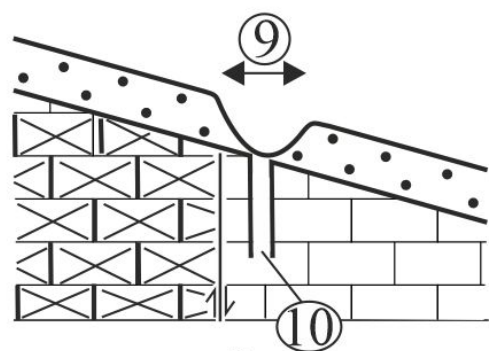

$\mathrm{e}$

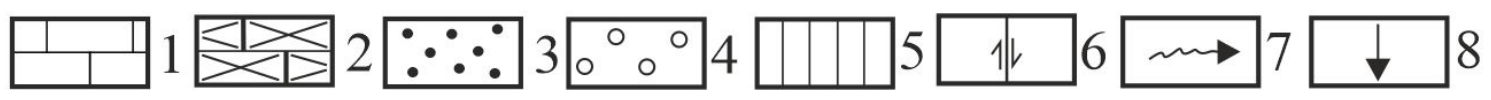

Figure 7. Development of subsidence dolines at various development environments: (a) above the mound of the bedrock at low accumulation cover thickness, $(\mathbf{b}, \mathbf{c})$. at cover that thinned out in an erosional way, (d) at the termination of covered impermeable cover, (e) at the margin of covered, intercalated non-karstic rock, 1. limestone, 2. non-karstic rock, 3. permeable cover, 4 . impermeable cover, 5 . reworked, partly impermeable cover, 6 . fault, 7 . water flow, 8 . infiltration, 9. subsidence doline, 10. shaft.

By denudation, a cover environment of small thickness may develop by pluvial erosion and linear erosion. Pluvial erosion happens when the bedrock is dissected by rows of mounds (Figures 8a and 9). Material is transported from the rows of mounds through the space between the mounds into the valleys resulting in the thinning out of the superficial deposit between the rows and in (suffosion) doline development. This can be seen on the blocks of Cretaceous limestone of the Northern Bakony Mountains [63]. Such doline formation is also expected on karsts dissected by mounds, but on buried karsts (for example Mediterranean karsts, tropical karsts) and on terrains between the mounds. 

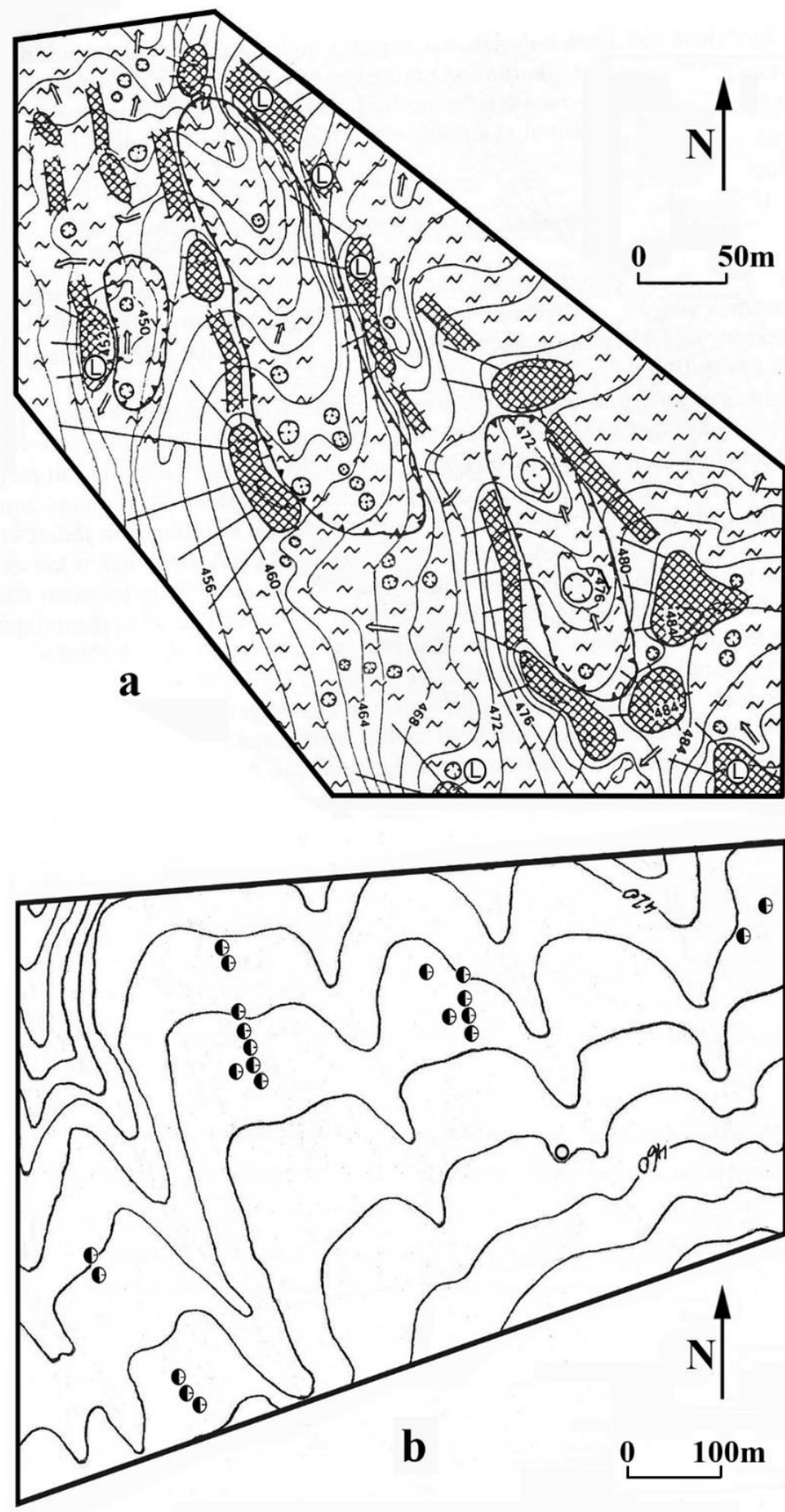

\section{0 $\Leftrightarrow 7 \Leftrightarrow 8 \leftrightarrow 99010 \div 11$}

Figure 8. Concealed karst: (a) between exhumed limestone mounds from Mester-Hajag (Bakony Region), (b) from interfluves from the environs of Márvány Valley (Bakony Region) [63]. Legend: 1. contour line, 2. exhumed mound, 3. semi-exhumed feature (it is ridge-like, but it does not constitute a mound) 4 . limestone outcrop on the mound 5. karstifying terrain with superficial deposit between mounds that developed by exhumation, 6. depression of superficial deposit, 7. material redeposition, 8. suffosion doline on the terrain between exhumed limestone mounds, 9. suffosion doline on interfluves, 10. suffosion doline on valley floor, 11. water drainage passage in a karstic depression. 


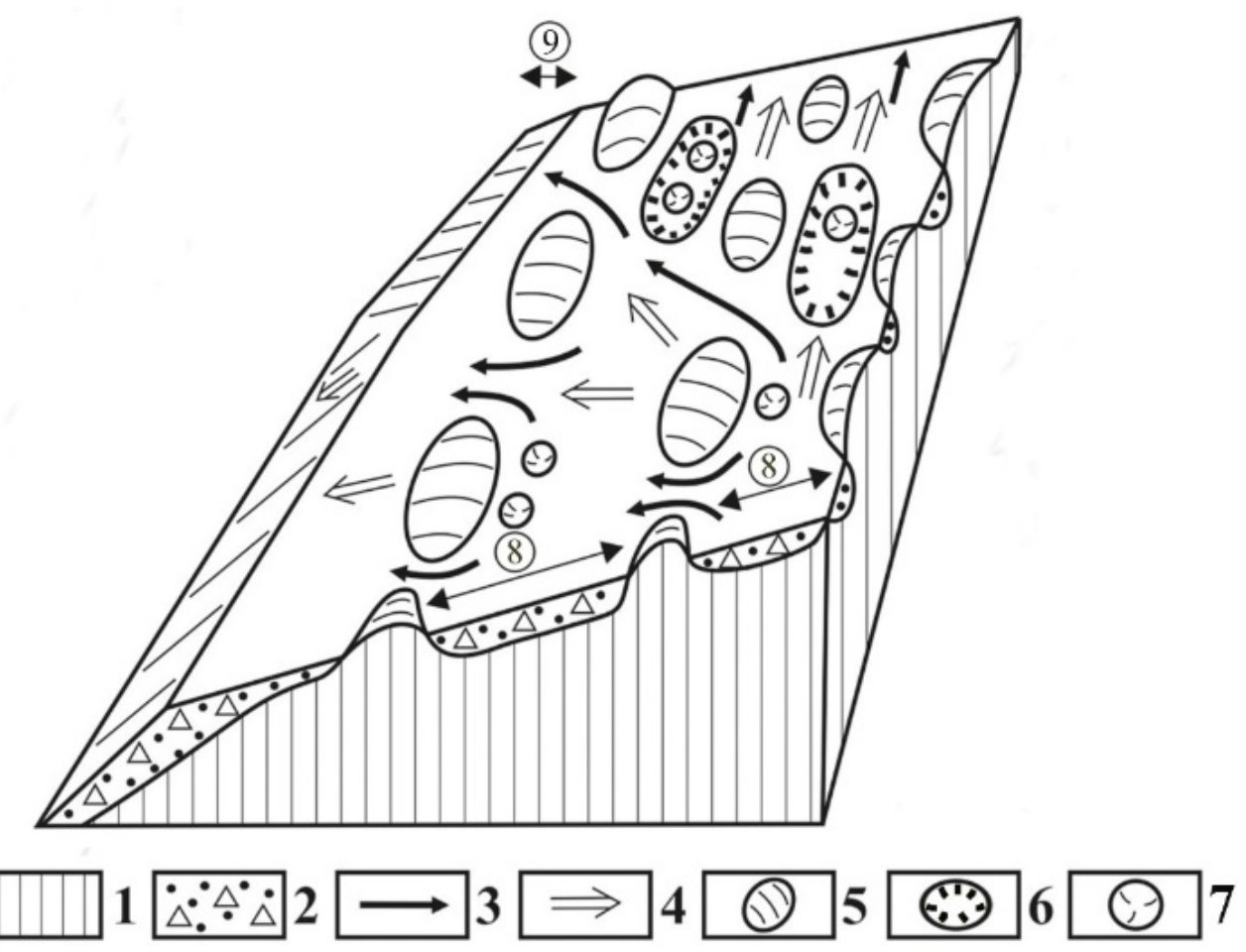

Figure 9. Karstification of a block dissected by limestone mounds if the block and its surface are inclined in two directions, one of the directions is parallel with the surrounding and sediment recipient valley. 1. limestone, 2 . superficial deposit and limestone debris, 3 . surface denudation by pluvial erosion and its direction, 4. dip direction of the surface, 5. exhumed limestone mound, 6 . depression of superficial deposit, 7. subsidence doline, 8. lower plain (or low-inclined) surface of superficial deposit between cones, 9 . valley, valley side.

The superficial deposit can also be denuded from interfluves into the surrounding valleys. The narrower the interfluve, the greater the chance of denudation and thus, the thinning out of the cover and the chance of doline development is greater too (Figure $8 \mathrm{~b}$ ). This is the explanation for the fact that 64 dolines out of 74 suffosion dolines are on interfluves narrower than $300 \mathrm{~m}$ in the environs of Márvány Valley (Bakony Region, Hungary) (the width of the interfluve is given by the shortest distance between the axes of the adjacent valleys) and only seven dolines occur on interfluves with a width of 300-600 $\mathrm{m}$ [63]. The pattern of dolines is banded and their direction coincides with the direction of interfluves. However, cover thinning out sites and thus, subsidence dolines may also develop in valley sides, at valley margins, and on the slopes and margins of depressions by pluvial erosion. Thinning out sites affected by linear erosion may occur in valleys, creeks, and gullies (Figure 4, Figure 7b,c and Figure 10, [29]) where water surplus develops as a result of the confluence of surface waters. Suffosion dolines that developed on valley floors with thinned out cover have a row-like pattern and they follow the direction of valleys and the channels of valley floors. Suffosion dolines on the meandering channel floor of a glaciokarstic depression near Žabljak (Durmitor, Montenegro) constitute a meandering row [11]. 


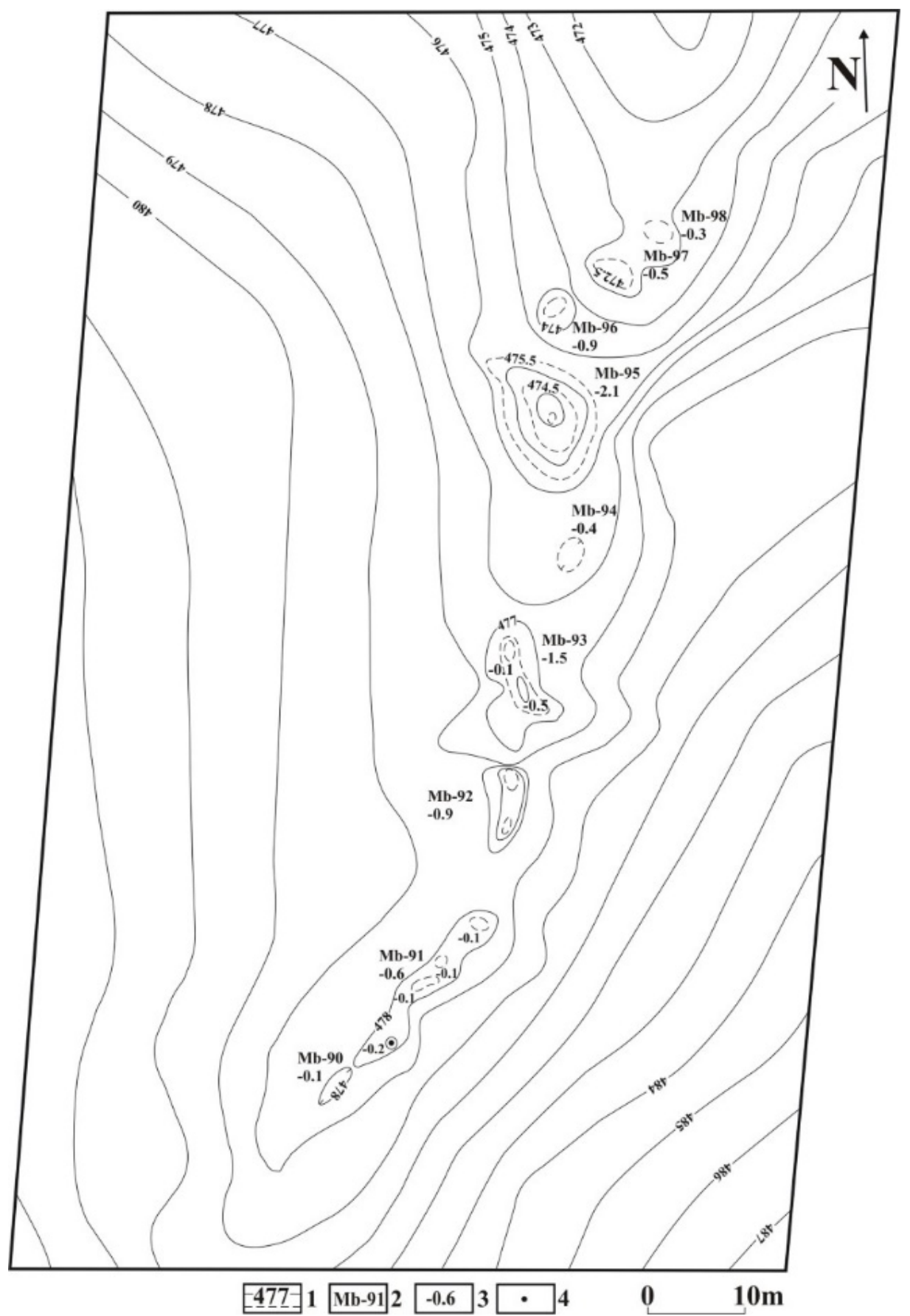

Figure 10. Floor dolines of creek (Bakony Region) [11]. 1. main and auxiliary contour line, 2. doline identification mark, 3. doline depth, 4. passage of doline.

Valley floor dolines are aligned in rows of various length (but they may be solitary too). Doline rows are in accordance with the thinning out of the valley floor cover. They occur at sites where the bedrock is of elevated position, or where the cover was denuded to a greater degree. A similar case can be seen in the Bakony Region. Out of the already mentioned 43 studied dolines, 15 dolines are on the valley floor [63].

Cover thickness may also increase doline development subsequently [18]. Filling may take place at inactive doline, but active doline as well (multiphase doline development). It probably happens on loess areas in case of repetitive falling dust of glacials. On such areas, one-phase doline development (the doline developed following loess formation) and multiphase doline development may be present adjacently. 


\subsubsection{Grain Size}

Grain size affects the direction of water motion and thus, the material transport of the cover. During a model experiment, syngenetic doline development [40] and karren formation [86] was studied on plaster plate with cover (point-like water supply by dripping resulted in dissolution and suffosion). There was widespread dissolution below a coarser cover with a grain diameter of $2.5-5.0 \mathrm{~mm}$ (solution features were formed in continuous development, in great density on plaster), while local dissolution occurred under a cover with a grain size smaller than $0.063 \mathrm{~mm}$ (dissolution takes place below the site of water supply, but a large feature is formed there). This can be traced back to the fact that the size of aggregate pore volume and capillary pore volume [87] and thus, water motion in the cover depend on the size of grain diameter [87]. In case of coarser-grained cover aggregate, pore volume is large, but in case of finer-grained cover, capillary pore volume is great. Therefore, in coarse-grained cover, the water has a gravitational motion, it reaches the plaster surface and moves there (water is dispersed), thus, dissolution is continuous on the bedrock. Fine-grained cover has a great water lifting capacity, therefore, the water stays in the cover, fluctuates, and percolates horizontally $[86,88]$. Dissolution is local because the water reaches the bedrock locally, below the site of water supply. The secondary porosity of the bedrock is widespread under coarse-grained cover, and suffosion is vertical. The secondary porosity of fine-grained cover is of limited development (dissolution and only occurs at certain sites, for example, at the already mentioned water supply site or where the continuity of the cover is disrupted), and suffosion is of partly horizontal direction [86].

According to the experiment, a lot of sediment recipient passages can develop on karsts even in the case of coarse grained cover and point-like water supply, into which suffosion material may be transported [86]. When the cover is fine grained and the water supply is point-like, few sediment recipient passages develop and suffosion material transport is absent or to a lesser extent. In case of coarse-grained cover, suffosion dolines are formed in greater number and with higher chance. (However, when the grain size of the cover is larger, suffosion is replaced by grain fall.) When the cover is fine-grained, as a result of the sticking of the grains and horizontal suffosion, there is a greater chance of the development of syngentic dropout dolines, the density of which is small since the density of drainage passage on the bedrock may be lower too.

The clayey fill of depressions increases in volume during water uptake, as a result of which, water motion is also horizontal at these sites independently of grain size and reaches the side slope of the bearing solution doline $[89,90]$. This and the clay fills do not favor vertical suffosion in the fills either [29]. Therefore, even if the floor of the solution doline is potentially suitable for solution of doline development because of the adequate secondary porosity of the bedrock, no subsidence doline develops.

\subsubsection{Calcareous Content of the Cover}

For the water percolating through the cover, if it performs dissolution activity it is no longer able to dissolve on the bedrock if it reaches that in a saturated state. Thus, depressions can only develop on the cover in a postgenetic way. According to its calcareous content, the cover may be of two types: it consists of limestone debris (this may be frost weathering or dissolution residue or of glacial erosion origin, moraine) or sediment with various calcareous content (for example loess). According to Williams [91], in lack of biogenic $\mathrm{CO}_{2}$, there is no solution under a cover of calcareous content of a thickness of $45.72 \mathrm{~cm}$ any more, while Sweeting [3] states that saturation level exists only in the cover in case of a limestone debris thicker than $2 \mathrm{~m}$. According to Balázs's experiment [92] (on limestone debris with soil on it), water percolating through the limestone debris already became saturated at a depth of some tens of centimeters.

The place of the saturation level in the cover with calcareous content depends on the proportion of the calcareous content, on the cover thickness and on the quantity of the calcareous content as compared to depth. 
According to Trudgill [56,93-95], if the $\mathrm{pH}$ value of the infiltrating water is 7-9 and the calcareous content of the cover reaches $10 \%$, no dissolution takes place on the bedrock any more. On the Tés Plateau (Hungary) where the doline density is 3.73 doline $/ \mathrm{km}^{2}$, the calcareous content of the loess is $21-31 \%$ [96], which can reach $34 \%$ in the environs of some subsidence dolines [97]. Therefore, either the dolines are postgenetic here [67], or the $\mathrm{pH}$ value of the infiltrating waters is lower here than the above-mentioned value. On the Western Mecsek Karst, where doline density is large, the calcareous content in the cover is $0 \%$ [66]. Although great doline density refers to postgenetic development (it is probable that significant cavity formation took place below the former karstwater level being close to the surface on the abrasion platform), the lack of calcareous content and the thin cover (mostly some meters) may even favor syngenetic development at some of them.

\subsection{Bedrock Hydrology}

The increase of water inlet into the cover may be triggered by rock quality, landscape features, and meteorological event. The role of vegetation can also be mentioned here. Thus, for example the presence of vegetation restrains the in-wash of superficial deposit from the area of the doline into the karst. A larger quantity of water increases dissolution both in the bedrock and in the cover and suffosion in the cover.

\subsubsection{Water Inlet at Rock Boundary}

Rock boundary can develop at the termination of superimposed (impermeable rock at the surface) and intercalated (impermeable rock is in the permeable rock) non-karstic rock, where waters flowing down from impermeable non-karstic rocks result in water surplus. In case of superimposed non-karstic rock, the more impermeable the cover, the more water can get to the rock boundary. If the cover is fully impermeable and widespread, mixed allogenic autogenic karst develops (this case is ignored here since it is not the subject of this study). If the impermeable bed is superimposed by permeable cover and the cover is less widespread, no mixed allogenic-autogenic karst develops. The water percolating through the permeable cover reaches the karst at the termination of the impermeable bed and dolines develop there [63]. Dolines have a linear pattern. The water arriving at the rock boundary may originate from meteoric water, surface stream or from the water flowing in the cover. The depression has a banded pattern, mainly linear. They are syngenetic, but the more banded their pattern, the greater the chance of the occurrence of postgenetic depressions among them. Their varieties are the following:

- The karstic rock is overlain by impermeable cover patch. Permeable sediment is present in its continuation, but on the impermeable cover too. Infiltration increases at the termination of the impermeable bed if the surface of impermeable rocks dips in the direction of karstic surfaces. Suffosion dolines are formed at the termination of the impermeable bed (Figure 7d). Such environments occur on fluviokarsts where patches of the impermeable cover may survive in the side of epigenetic valleys and rock boundaries develop at the margins near the valley floor.

- Impermeable intercalation may be present in the cover too. This intercalation directs the water accumulating above it to the wedging out of the impermeable bed, where a subsidence doline may develop since the water moves downwards here. This may occur at thinning out cover superimposed on horizontal bedrock where the impermeable bed terminates, for example, in the Bakony Region or at the wedging out impermeable bed of the cover of solution dolines such as on the Western Mecsek Karst [11].

- It may happen that the depression does not develop at rock boundary but on clay that superimposed on limestone where the porosity of the bedrock is locally high, for example, in Florida (Figure 11, [18]). The depressions do not have a linear pattern and develop above karstwater cavities, thus, they are postgenetic.

- A rock boundary resulting in depression development may be formed in case of not being superimposed, but intercalated rock if the non-karstic rock dips towards the 
karstic rock because of the tilting of the bearing block (Figure 7e), where the two rocks reached a similar elevation by faulting. Such rock boundary can be mentioned from the Bakony Region [63]. Syngenetic depressions with linear pattern develop at the border of karstic and non-karstic rocks when the karstic rock is overlain by permeable cover.

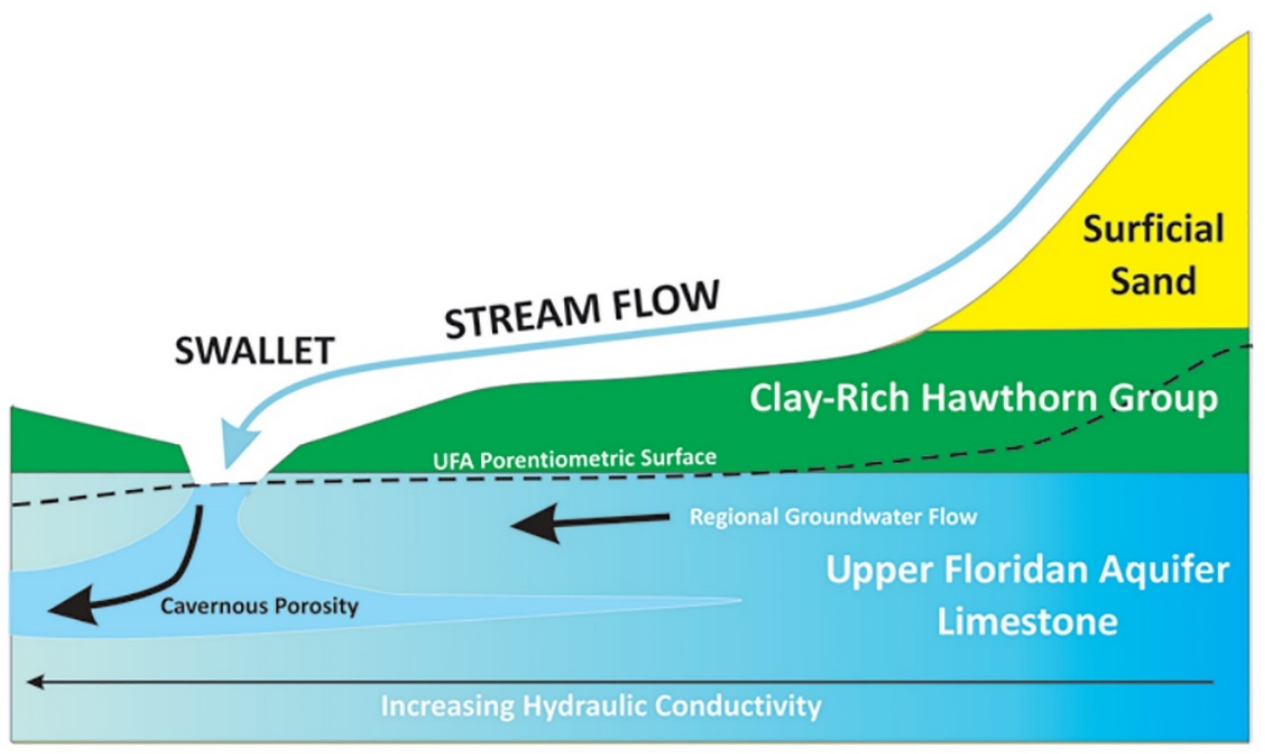

Figure 11. Subsidence doline development on clay [18].

\subsubsection{Water Inlet at Surface Features}

Some features may collect the waters of the surrounding terrains and thus, they increase the quantity of the water getting into the karst. The features are the following:

- In erosion features (in fluvial valleys, creeks, gullies, and glacier valleys), mainly the water accumulates on valley floors results in water surplus if the surface runoff of meteoric water is impeded. This is particularly significant where the valley floor is of low gradient (above the limestone outcrop restraining valley incision), where the valley floor is anti-dip (glacier valley) or where a permanent water course is on the valley floor because of the closeness of the karstwater level such as in Florida [18]. This environment is particularly widespread on fluviokarst, on glaciokarst, and on taiga karst. On glaciokarst, in addition to glacier valleys, it is also widespread in creeks that were formed on moraine and in gullies too. However, on interfluves as well, as already mentioned, doline density increases because of the indirect effect of valleys since the latter play a role in the transportation of the cover of the interfluves and thus, in their thinning out.

- Closed features and karst depressions (doline, depression of superficial deposit, uvala, polje) particularly favor the development of water surplus. Subsidence dolines can develop in depressions with superficial deposit such as in the paleo dolines of glaciokarst [14], in the cockpit dolines [69] and fengcong dolines of tropical karst, in the poljes of Mediterranean and tropical karst [3], in the dolines, uvalas, and depressions of superficial deposit of temperate karsts or on the areic or nearly areic terrains between the mounds of the exhuming limestone bedrock [11]. Water surplus in the depressions is indicated by larger and smaller valleys leading to them or on their floor, the springs at the margin of depressions (Figure 12). Sites of water accumulation thus, sites of water surplus can occur at the deepest points of smaller depressions, at the foot of the slopes of larger depressions (if the floor dips towards the side slope), and on their slopes, particularly at places where the cover is thinning out because of its denudation. At the deepest point, the pattern of subsidence dolines is local, at the foot of the slope it is an arcuate row. The latter are close to the rock boundary (Figure 12). 
Probably, there is a relation between the grain size of the fill of subsidence dolines and that of the bearing depressions since grain size affects the direction of water motion in the cover. Thus, as a result of great aggregate pore volume, water motion is vertical in coarse-grained cover, which favors subsidence doline development. In the cover of the depressions of Pádis containing sandstone debris as a result of vertical water motion, cover beds of low position are thinning out by material loss and create a depression into which the upper beds are deflected and thus, a doline develops at the surface (Figure 13, [47]). Similarly, dolines occur at the deflections of sand cover on the coastal karst in Florida [98].

- $\quad$ On karst rocks, stepped surfaces may be formed independently of rock quality (for example on glaciokarsts). Stepped surfaces are dissected by scarp fronts (escarpments). If the beds are inclined, the surface with bedding planes dips towards the escarpments, as a result water surplus can develop in the filled solution dolines at their feet, which favors subsidence doline development. The developing subsidence dolines have a banded pattern and asymmetric cross section (Crimea Peninsula, Figure 14).

- If their drainage decreases, subsidence dolines are filled with water in the rainy season [29]. The overflowing water of intermittent lakes results in water surplus in their environs, which causes the development of newer subsidence dolines at new absorption sites. The presence of channels leading from inactive dolines to active dolines is evidence for this [67]. The overflowing water of permanent lakes may also cause subsidence doline development [58].

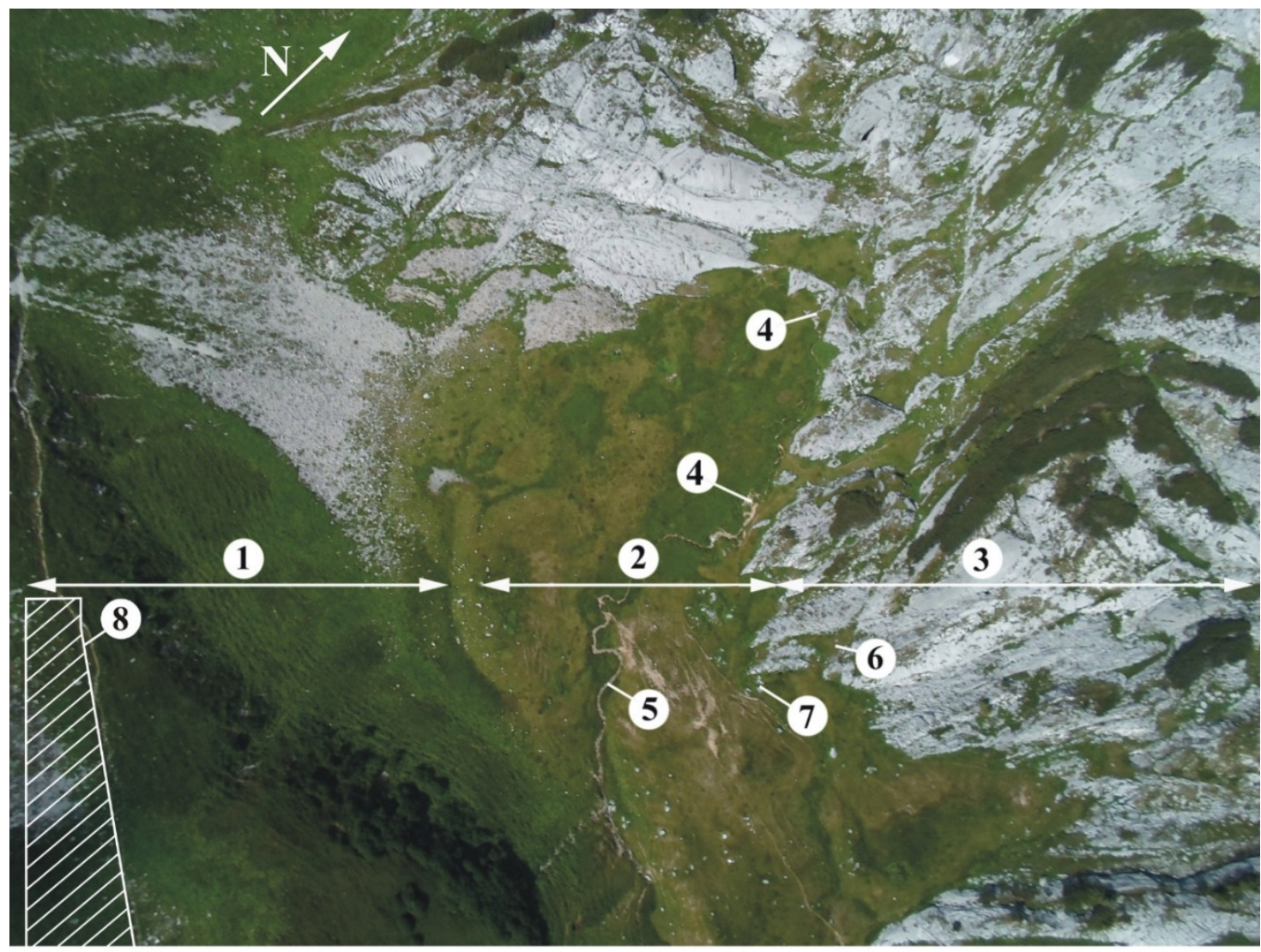

Figure 12. Aerial photograph of the area of paleouvala, which is under Wildgössl (Totes Gebirge, photo taken by Kalmár). 1. side of paleouvala with debris fans, 2. floor of paleoouvala with superficial deposit, 3. slope of paleouvala with glacially eroded cuesta, 4. covered karst ponor, 5. gully, 6. covered karst terrain intruding into the depression of the cuesta, 7. a subsidence doline in the zone of thin superficial deposit next to rock boundary, 8. zone of springs. 
VII $\quad$ VII'

SW NE

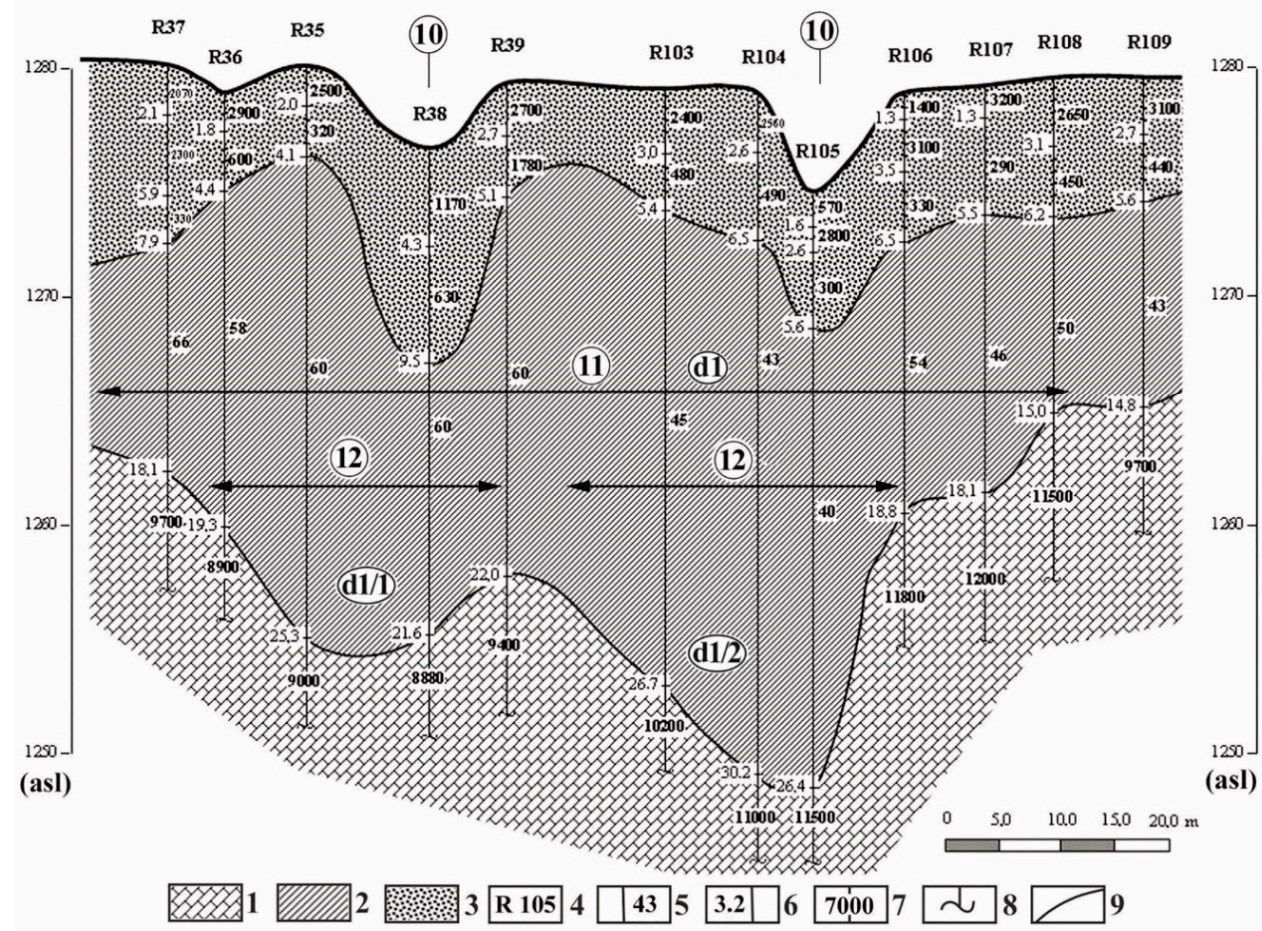

Figure 13. Subsidence dolines above floor drawdown dolines of plain-floored depression (Pádis, Románia) [47]. Legend: 1. limestone, 2. clayey silt, 3. mixed rock debris (sand, sandstone and limestone debris), 4 . site and identification code of VES measurement, 5. geoelectric resistance of series (Ohmm), 6. base depth of geoelectric series (m), 7. geoelectric resistance of bedrock (Ohmm), 8. approximate depth of penetration of VES measurement, 9. geoelectric series boundary, 10. subsidence doline, 11. large-sized depression on the bedrock with identification code, 12. inner depressions of the large-sized depression with identification codes, $\mathrm{d} 1 / 1$ and $\mathrm{d} 1 / 2$ are identification marks for part depressions.

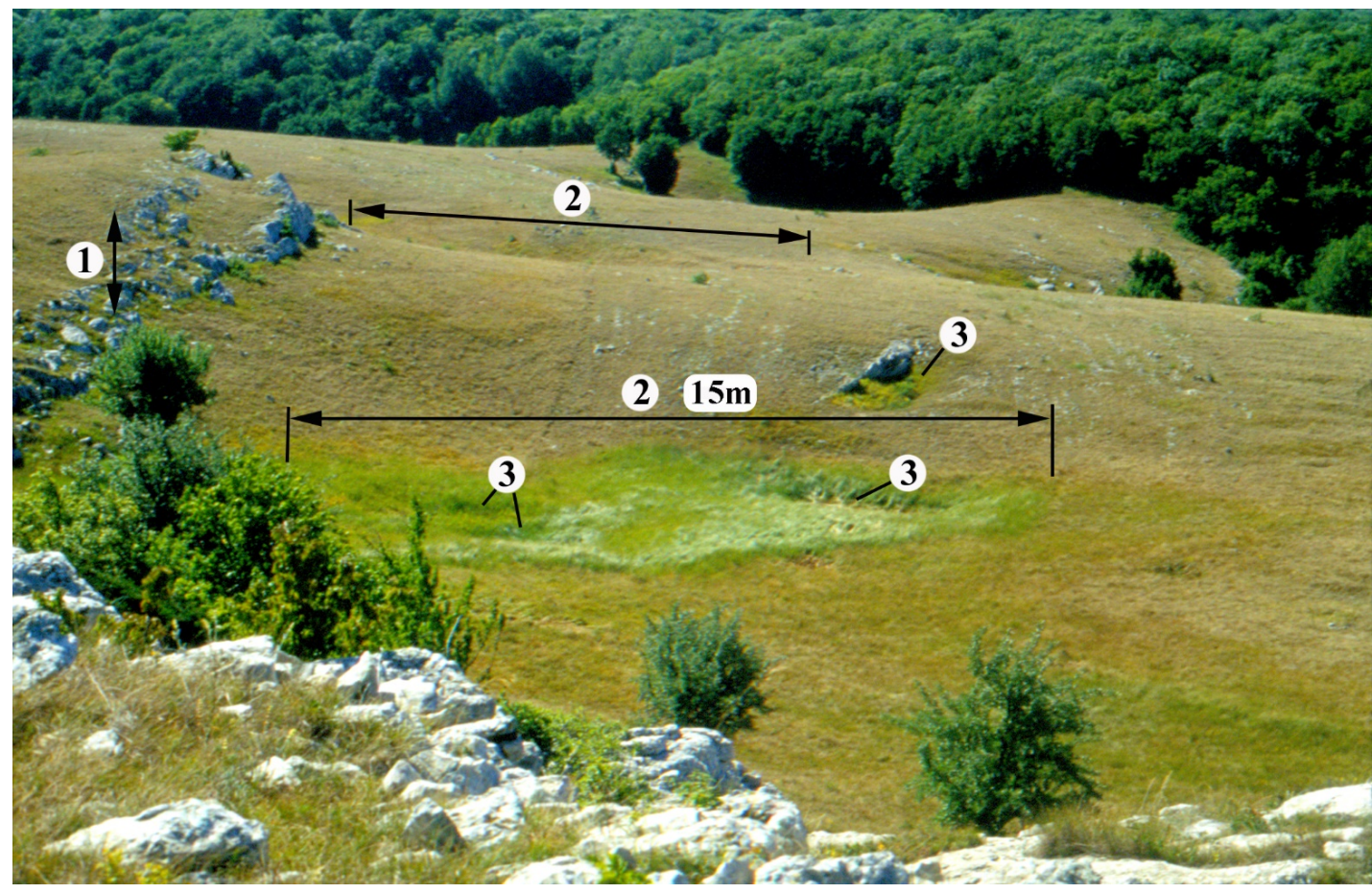

Figure 14. Subsidence dolines of cuesta terrain (Crimean Peninsula). 1. cuesta, 2. solution doline, 3. susidence doline. 


\subsubsection{Rainfalls}

The quantity of water infiltrating into the cover increases to the effect of intensive, long-lasting, repeating rainfalls or snow melting. The developing water cover may also be continuous, which results in the spread of infiltration. Depression development is of collapse and postgenetic origin, the process is intensive and the pattern of dolines is areal. If valleys are present, water flows in them. The time when collapses happen after the increased rainfall may be very different, but the duration of collapses also depends on the quality of the cover. Experience of observations show the effect of intensive rainfalls well, which also report on doline development occurring at that time. Thus, in the valley of the River Flint (Dougherty Plain, at Albany, Georgia) 312 dropout dolines developed in alluvium within $48 \mathrm{~h}$ following intensive rainfalls in 1994, but dolines already existing preceding rainfall significantly widened too [99].

Increased water quantity may have the following results.

- $\quad$ Flood lakes develop in depressions since drainage passages become plugged either temporarily, but of complete degree or partially. The weight of the lake water may be the cause of collapses (smaller dropout dolines of floor position may develop), but the continuously percolating water also increases the saturation of the fill (as a result cover cavities may collapse). To the effect of the water continuously infiltrating from the lake, the chance of suffosion increases both in the cover and in the passages of the bedrock (the fill of the latter may also increase). Lake development may also increase the chance of the development of postgenetic inner (floor) dolines or the reactivation of the already existing dolines [100].

- The water arriving at the cover redeposits the superficial deposit, while it compacts it during its emptying and the chance of cavity formation in the superficial deposit increases.

- The superficial deposit is filled with water, which may restrain material transportation from the cover.

\subsection{Water Level Changes}

Both the rise and the fall of water level affects doline development if the water level is close to the surface. This is usually valid when the karst surface is close to the base level of erosion. At a water level close to the bedrock surface, cavities close to its surface are formed, which make intensive material transport from the cover possible. Water level is close to the surface in the following cases:

- The karst has been karstfying for long and intensively such as in the area of intermountain plains where the water level is at the surface of plains because of this and because of the rest position of the karst $[15,101]$.

- The karstic rock is thin and its bedrock is impermeable non-karstic rock for example on the Lagoa Santa Area karst in Brazil [30].

- On fluviokarst where the incising streams reach the karstwater level if the karst originally has a low elevation, such as in the area of Florida [18].

- The karst is of low elevation either because it subsided (the Adriatic coast) or it is of low altitude originally (coast of Florida).

- As a result of the non-karstic denudation and subsidence of the surface, for example, at the poljes of the Dinarides.

In the above-mentioned case, a large number of subsidence dolines develop with areal pattern (Figure 15). Water level changes primarily contribute to postgenetic doline development. Decreasing water level results in cover compaction, suffosion, and collapse [5,29]. Doline formation takes place when the water level subsides below the bedrock surface (Figure 16, [7,78,102,103]). Water level decrease in the cover may also be independent of karstwater level changes, for example, it is determined by the flowing water level [31], or by the sea level. The degree of water level change, at which doline formation occurs, may be very different: for example 1-2 m [104], $3 \mathrm{~m}$ [78], 3-5 m, but different in various seasons 
too [31], and it can even reach $24 \mathrm{~m}$ [33]. Doline development can be triggered by water level decrease in the cover and in its cavity [31] or if it takes place in the bedrock [105]. It is probably of various degree because in addition to the position of the karstwater level, doline development also depends on cover composition, the intensity, and distribution of water supply, and on the characteristics of the secondary porosity of the bedrock. Thus, if there is a cavity in the bedrock, the drop of karstwater level causes its collapse since its ceiling is thin and its support is small because of its horizontal expansion [5], which can be inherited onto the cover by collapse [58], resulting in dropout doline development. The appearance of water or water loss in the cover affects doline development in the following way:

- The appearance and percolation of water in the cover results in horizontal material redeposition.

- The chance of the cavity collapse of the cover is greater and greater as water level decreases in the cavity because of the increasing lack of support. Such effects can be caused by droughts, pumping and earthquakes. Water level both in the cover and in its cavity decreases permanently to earthquake effect [106]. There was a permanent decrease of $30-50 \mathrm{~cm}$ in water level after the earthquakes at the depressions of Mečenčani [37].

- The appearance of water above the already present cavities in the cover increases material weight and thus, the chance of collapse.

- Water loss results in compaction triggering surface subsidence.

- The decrease of water level increases vertical suffosion in the cover, which results in cavity formation.

- $\quad$ The water in the cover increases the destructive effect of earthquakes and thus, collapse development on the ceiling of cover cavities where the fluctuation of the water level [107] may increase the strain or the fluidization of the cover [108].

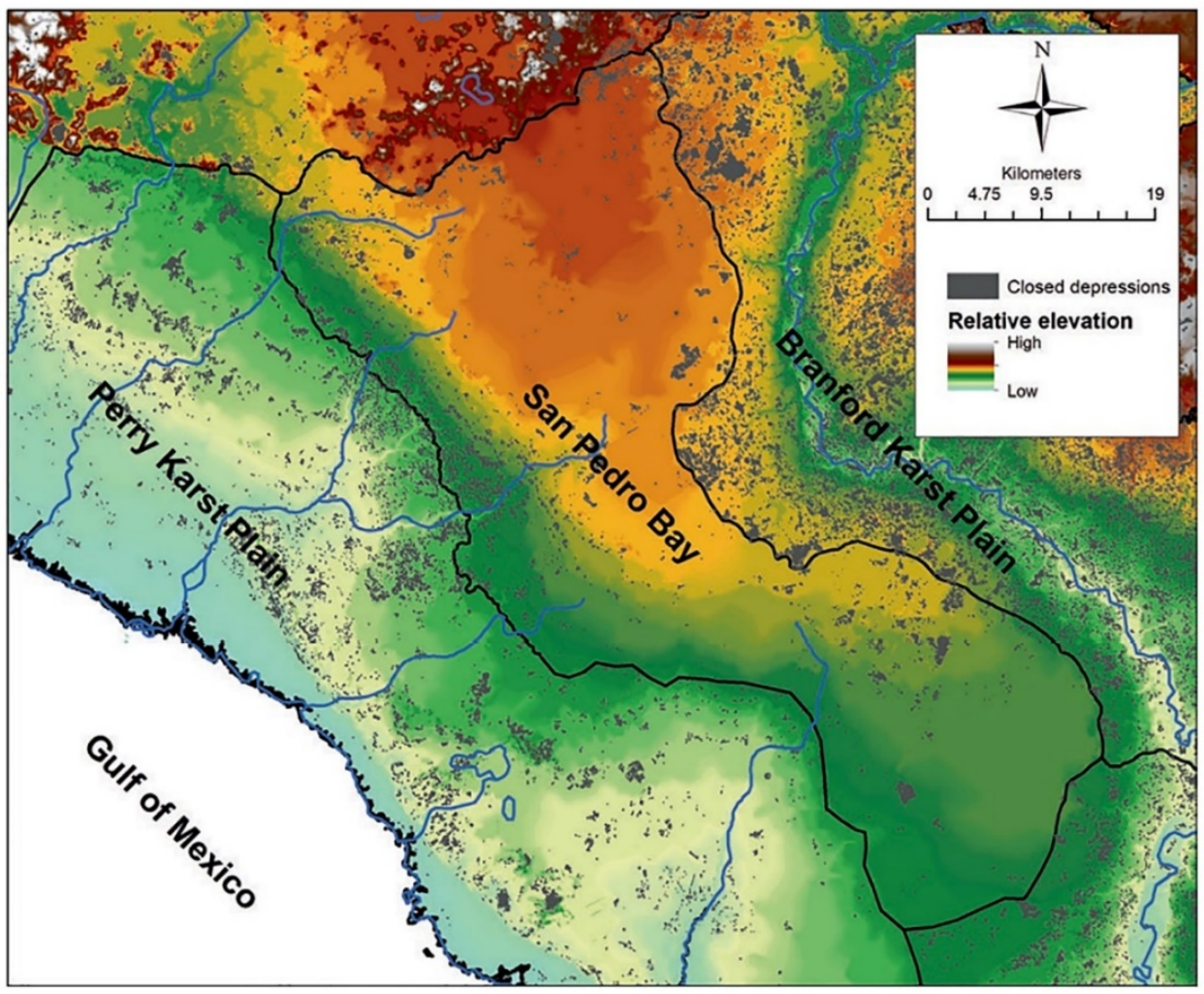

Figure 15. Depressions of coastal karst, which have areal pattern [18]. 


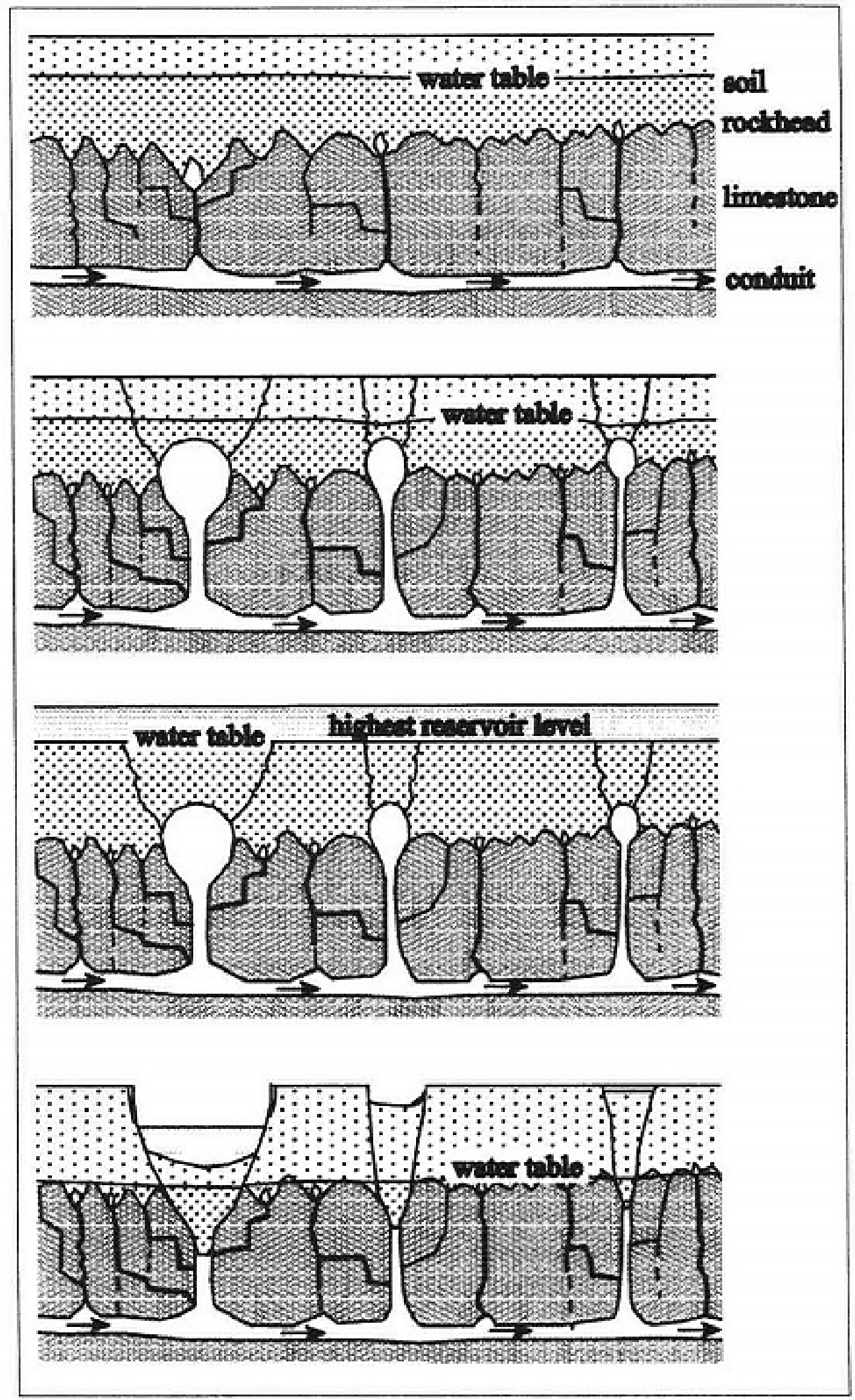

Figure 16. A model of dropout doline development at Konya in Turkey [7]. 
Water level fluctuations are oscillations, which may be of short, long, and very long duration (during short term oscillations, high and low water levels develop creating the epiphreatic zone with epiphreatic cavities). The vertical movement of the bearing area and climate changes may cause very long oscillations. However, since they result in water level changes of low rate, they probably do not affect the process of covered karstification, for example, because their duration may exceed the existence of superficial deposit (disregarding glacials and interglacials, which affect doline development through the change of sea level). Water level oscillation of short duration may occur due to the rise and drop of the karstwater level (rainfall, droughts, anthropogenic activity, tide), while water level oscillation of long duration is the result of sea level changes. Under natural circumstances, karstwater oscillations of short duration occur at sites where the karst is of low elevation, the water level is close to its surface and dry and wet seasons alternate. Thus, at the intermountain plains of inselberg karst [15], or at poljes, which may be intermittently flooded by karstwater [5,109-111] (oscillations of long duration may take place at coastal karsts with low elevated surface for example on the Adriatic coast, or in Florida $[18,98])$. In the case of coastal karsts, water level changes of long duration may be modified by oscillations of a short period (Figure 17). To the effect of water level fluctuations, doline development is postgenetic and doline pattern is often areal.

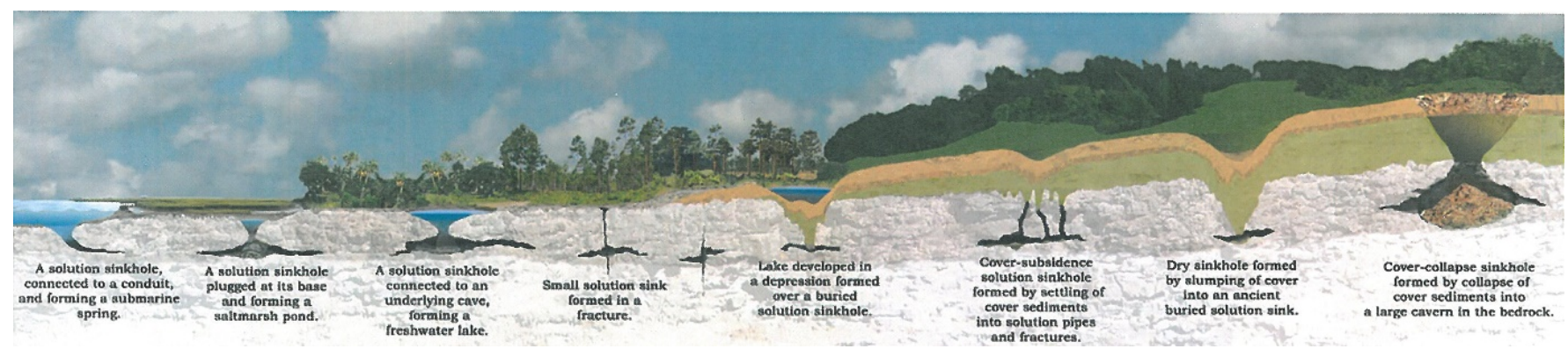

Figure 17. Subsidence dolines and solution dolines of coastal karst, which have various elevation and thus, genetics [98].

For water level fluctuations, the material recipient passages of the bedrock are of phreatic or epiphreatic origin. The lower the gradient of the karstwater level and the greater its fluctuation, the larger area material transport affects and more intensively. The greater the passage density and the larger the passages, the larger the extent of cover transport and thus, doline size and doline density may be. The more developed the cavities of karstwater horizontally, the more collapse origin the doline development and the more direct process inheritance is. If the dry season (karstwater level is below the surface of the bedrock) is disrupted by smaller rainfalls (suffosion), this favors the degree of material transport from the cover. It is known that in areas of sunk water level, the tendency to doline development increases during rainfalls [29], but lake development decreases the chance of doline development [112], since this can probably be related to water level rise. Smaller rainfalls do not cause significant karstwater level rise that reaches the cover, but promote and enable suffosion material transport from the cover. Short-termed oscillations of the karstwater level may affect the following sites (Figure 17).

- Only the cover is affected when there is no vertical suffosion material transport and suffosion doline development either. However, there is dropout doline development since groundwater decrease triggers cavity formation in the cover even without reaching the bedrock level [31]. The collapse of the cover can be caused by several factors (for example earthquakes [37]). Basically, dolines of such development may also be formed independently of the karst.

- $\quad$ Only the bedrock is affected by which suffosion processes and thus, doline development may take place during the whole year, the transported part of the superficial deposit gets into the karstwater and settles down at the arriving site or it is transported further during flow. 
- Oscillation can be spread both onto the cover (high karstwater level) and the bedrock (low karstwater level). Suffosion only occurs at low karstwater level, thus during rainfall in the dry season (1) or at the end of wet seasons (2), when the water level is in the bedrock and suffosion can take place from the cover (of course, cover cavity collapse and thus, dropout doline development may happen during the sinking of high karstwater level when the karstwater level is still in the cover). Suffosion takes place until the water level does not rise above the bedrock surface, which happens at a certain quantity (intensity) of precipitation. If the elevation of the water level exceeds the elevation of the bedrock surface, suffosion only takes place within the superficial deposit, suffosion doline development, and the growth of the already developed dolines stops (dropout doline development may take place of course). The time and duration of the interruption of material transport from the cover depends on the quantity and distribution of precipitation, and on the position of the karstwater level as compared to the bedrock surface. It also depends on the degree of the water level rise at a certain quantity of precipitation, which is determined by the degree and pattern of cavity formation.

- It can also affect the surface when the elevation of the high karstwater level may exceed the elevation of the surface. The fluctuation of the karstwater level results in the development of katavotra (estavelles). Lakes of fluctuating level are formed both on tropical karst and Mediterranean karsts [3]. In this case, the rising karstwater creates passages opening onto the surface (from the upward moving water, barrierlike sediments are formed around them.) The intensity of depression development increases since precipitation and streams accumulate superficial deposit into the open (opening onto the surface) passages. Thus, the katavothron (estavelle) and the subsidence dolines around it is turned into depressions of superficial deposit. Newer subsidence dolines are formed inside the depression of superficial deposit (Figure 2C, [11]).

Karstwater level sinking of long duration may take place during the glacials when the karstwater level follows the sinking of the sea level [109], and because of the drier climate of the glacials. Because of the above-mentioned facts, there were low and high karstwater levels of different elevations in the glacials and interglacials. Where the low karstwater level was also at the surface in the interglacial, only subsidence dolines that were formed in the glacial occur. Where the karstwater level did not reach the surface, subsidence dolines could also develop in the interglacial (Figure 18). The limit of doline development related to the karstwater level, which depends on altitude, is determined by the high karstwater level of the interglacial. The dolines of coastal karst that developed in the glacial are filled with sea water or impounded karstwater at various degrees as a result of the rise of the sea level (Figure 2D, [16]). Depending on the altitude of depressions, the lakes may be more and more intermittent and meteoric water plays a role in their development rather than karstwater and/or sea water [98]. In the coastal zone, at the maximum level of karstwater, dropout dolines may develop by direct inheritance with the collapse of cover cavities or following the collapse of cover cavities at cohesive cover, which dolines mainly developed in the interglacial. In the glacials, there is a greater chance of the development of suffosion dolines. 


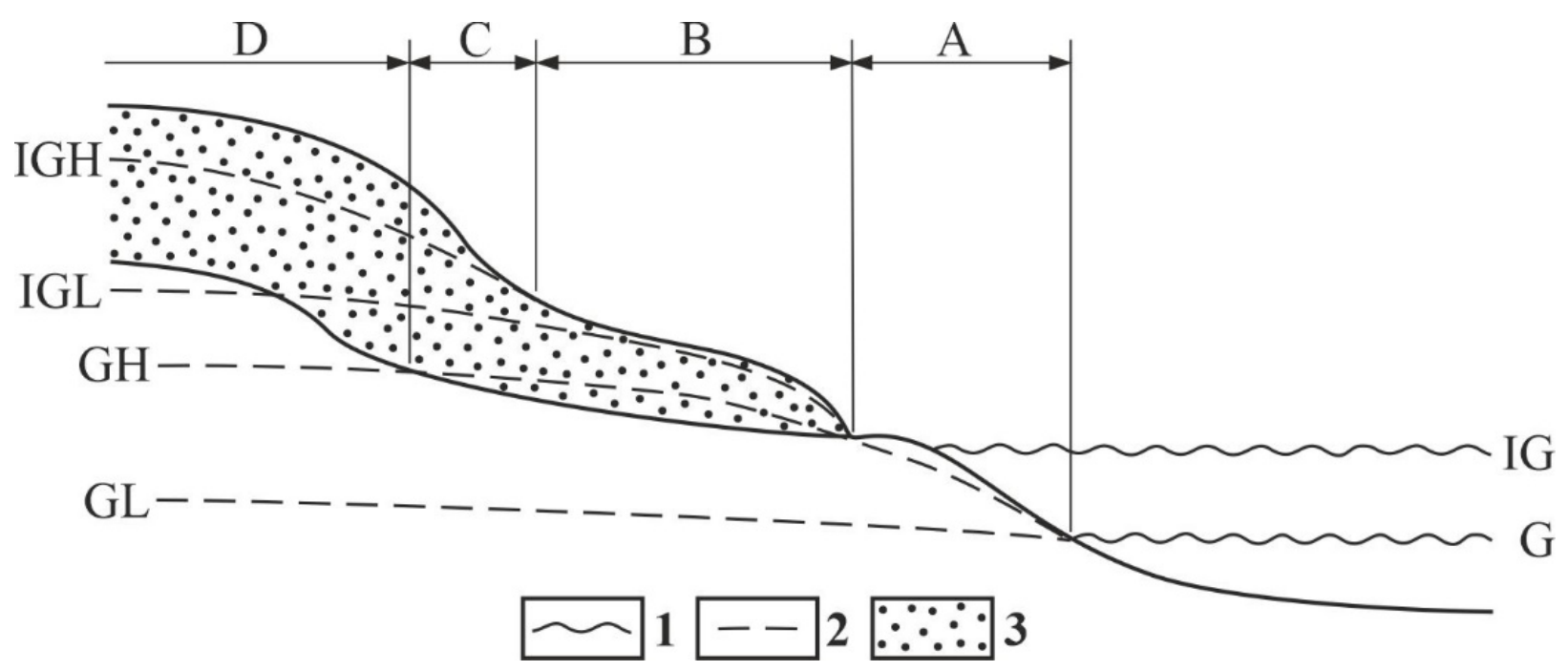

Figure 18. A possible model of doline development on coastal karst in glacials and interglacials 1. sea level, 2. karstwater level, 3. non-karstic permeable cover, G. sea level of glacial, IG. sea level of interglacial, GL. low karstwater level during glacial, GH. high karstwater level in glacial, IGL: low karstwater level in interglacial, IGH. high karstwater level in interglacial, (A) zone of solution dolines, (B) zone of dropout dolines that developed in the glacial, the dolines of which are transformed into dolines with lakes in the interglacial, (C) zone of dropout dolines that developed in the glacial, (D) zone of suffosion dolines that developed in the glacial, in which dropout dolines may develop in the interglacial.

\subsection{Permafrost Degradation}

On taiga and tundra areas as a result of permafrost [113-115], karstification and covered karstification have specific characteristics. On permafrost, subsidence dolines can be formed at sites where latent heat transmission takes place from below [116], at the pointlike infiltration sites of surface waters [5], to their melting effect, at salty groundwaters [117], at paleokarstic passages [118-120], and where the ice plug of the paleokarstic passages ice is broken through by waters accumulating at the surface [5], or permafrost is interrupted by talik [17].

\subsection{Anthropogenic Activity}

Human activity such as on the Italian gypsum karsts may induce subsidence doline development [121-123]. Dolines may develop in a natural way when human activity plays a role of some degree [124], or when human activity is predominant in the process [125,126]. The development rate of Italian (Sicily) subsidence dolines is different depending on whether they were formed in a natural way or to the effect of human activity [127].

Human activity that contributes to doline development is the change of water balance and mining, but vehicle transport, artificial explosions, and construction work that change the existing balance and agricultural activity (for example vegetation removal) can also play a role in the process. The change of water balance may happen by water input and water output. Water surplus may develop when flushed water is used in the boring hole, which results in rapid dissolution when reaching the evaporate rock $[128,129]$. During water withdrawal and then letting the water flow, water infiltration sites develop increasing suffosion. Irrigation water increases the load of the cover and thus, causes doline development [29]. Water loss from the cover may be spontaneous when the water is drained into a tunnel [130], or into a mine [36,42,131]. Suffosion may be caused by the percolating water of water pipes [29,125,126], by water well drilling [58], by subway construction work [31], or by gypsum quarrying [132]. Water level reduction may be active in case of drinking water pumping [104], or the protection of works of art [103] may also be a reason for water level reduction. It may occur that the tendency to doline development increases when artificial water level reduction is related to construction work in the mine workings [133]. The main cause of doline development is the active karstwater 
level reduction. Several hundreds, thousands, or even tens of thousands dolines may develop at that time $[22,36,42,79,102-104,134,135]$. However, doline development occurs if surface water reaches onto the evaporate bedrock through the borehole too [131]. Doline development takes place in some hours, days, or months following artificial water level reductions $[36,42,102,130,134]$. Doline development as it has already been mentioned, may occur at water level sinkings of various degrees.

Doline development may also be related to mining. In this case, the way of feature development is determined by the quality of the cover and the fact whether material shortage is inherited indirectly or directly onto the cover. (In the former case, the superficial deposit is transported into the fissures or passages of the bedrock, while in the latter case cover motions follow bedrock motions.) Thus, material shortage triggered by mine cavities can be equalized in the following ways:

- $\quad$ The surface subsides above the mine cavity [136]. Tension takes place at the margin of the subsided area and atectonic fissures develop [136]. Thus, both indirect and direct feature development may occur in the tensional zone at the surface (see below).

- The collapse of the mine cavity is inherited onto the vault where cavities are formed and their collapse results in depression development [137].

- $\quad$ By collapse, the mine cavity is directly inherited onto the surface where collapse features develop [138-140], among which subsidence dolines may also occur depending on the cover quality.

- Above the mine cavities of evaporates, breccia pipes develop by dissolution and/or collapse and they reach the surface where features are formed indirectly $[74,137,141,142]$.

- Above the mine cavity, only the cover collapses and also results in indirect feature development at the surface $[143,144]$.

It can be seen that there are development ways when karstification is not an exciting agent of the phenomenon. Therefore, dolines whose development is due to mining work may be karstic and pseudokarstic. The atectonic fissures (passages) of the bedrock that were formed as a result of subsidence, if cover is present, can be indirectly inherited onto the cover by its collapse, which can be accompanied with grain fall and suffosion. However, they can be inherited directly as well, when the collapse of the atectonic fissures of the bedrock is followed by cover collapse. On Mount Bocskor (Hungary) near Ajka, more than 100 pseudokarstic depressions developed in a banded pattern on the cover to the effect of displacements above mine cuts in the above-mentioned ways [11].

Depressions related to anthropogenic activity are mostly postgenetic, but on evaporates they may also be syngenetic. Those developing on evaporates or during artificial water level lowering have an areal pattern.

\section{Joint Effect of Development Environments and Factors on Doline Development}

Development environments and factors may be quantitative (surface inclination, secondary porosity of bedrock, the thickness, grain size and calciferous content of the cover, water level changes, anthropogenic activity), qualitative (permafrost), and partly qualitative (water supply into the cover). In the case of qualitative development environments, their presence is the precondition of doline development, at quantitative development environments there is an upper and a lower limit value (this is the development environment interval), between which doline development may take place, but not in all cases. The value interval of some development environments is the most favorable for doline development when it is low (the lowest within the interval), while at other environments, if their value is high (the highest within the interval), but it may also happen that no upper limit exists (for example rainfalls). Examples for the former are the inclination of the surface, the cover thickness, and the calciferous content of the cover, while for the latter are secondary porosity, the grain size of the cover, and the degree of water level sinking. It may occur that both a high and a low value are also suitable for doline development. At that time, its degree controls the type of doline development. Thus, at small grain size, dropout dolines develop, while at large grain size, suffosion dolines develop at a greater chance. 
At some development environments, the upper or lower value of the interval determines, for example, the upper value of the dip angle, the occurrence of development, while at others, the interval limit is not significant (thus, the upper limit of cover thickness). The effect of some development environments is different at the development of syngenetic and postgenetic dolines. Thus, the calcareous content of the cover does not play a role in the development of postgenetic dolines. The upper value of the cover thickness development interval is greater at the postgenetic dolines. Water level changes of short duration primarily affect postgenetic doline development. The lower value of the precipitation fall development interval is lower in case of postgenetic doline development than at syngenetic doline development. The geological, geomorphological, and climatic conditions of the karst create the suitable quantitative value and qualitative value for the development environments. If in a karst area, only one development environment type is not suitable from the development environment group (disregarding those where the interval has no upper limit), doline development does not take place.

\section{Conclusions}

The development environment of the subsidence dolines is predetermined by the secondary porosity of the bedrock, the inclination of the bearing surface, the characteristics of the cover (thickness, grain size, calciferous content), bedrock hydrology (rock boundary, water collecting surface features, rainfalls), water level changes, thaw permafrost, and anthropogenic activity.

The doline development environments and factors are the following.

- Development environment group being independent of water level, when development is mainly affected by the surface morphology and cover characteristics. Dolines may be syngenetic and postgenetic.

- Development environment group dependent of karstwater level, when primarily water level changes are responsible for doline development, these changes are controlled by the intensity, and distribution of precipitation falls. The dolines are postgenetic with areal pattern.

- Anthropogenic development environment, when development is influenced by changes caused by society. Its effect mainly occurs on evaporates. The development is syngenetic and the dolines are of areal pattern on evaporites.

However, development only happens in case of the three environment groups if water supply and the secondary porosity of the bedrock are adequate.

On karsts with various geological, climatic, and hydrological characteristics, different development environments and environment groups are determinants. Therefore, the development of subsidence dolines may be of extremely different character, quality, and pattern (density) in various karst areas. A successful prediction of doline development at a given place is possible if we take into consideration the influencing environments (environment group) and determine their values. At the same time, in the knowledge of the characteristics and the development of the dolines, conclusions can be drawn to the development environments and to the geological, climatological, and hydrological characteristics that determine them.

Funding: This research received no external funding.

Institutional Review Board Statement: Not applicable.

Informed Consent Statement: Not applicable.

Conflicts of Interest: The author declares no conflict of interest. 


\section{References}

1. Gutierrez, F.; Parise, M.; De Waele, J.; Jourde, H. A review on natural and human-induced geohazards and impacts in karst. Earth Sci. Rev. 2014, 138, 61-88. [CrossRef]

2. Parise, M. Sinkholes. In Encyclopedia of Caves, 3rd ed.; White, W.B., Culver, D.C., Pipan, T., Eds.; Academic Press: Cambridge, MA, USA; Elsevier: Amsterdam, The Netherlands, 2019; pp. 934-942.

3. Sweeting, M.M. Karst Landforms; Columbia University Press: New York, NY, USA, 1973; 362p.

4. Williams, P.W. Dolines. In Encyclopedia of Caves and Karst Science; Gunn, J., Ed.; Fitzroy Dearborn: New York, NY, USA; London, UK, 2004; pp. 304-310.

5. Ford, D.C.; Williams, P.W. Karst Hydrogeology and Geomorphology; John Wiley \& Sons: Chichester, UK, 2007; 561p.

6. Gutiérrez, F.; Guerrero, J.; Lucha, P. A genetic classification of sinkholes illustrated from evaporite paleokarst exposures in Spain. Environ. Geol. 2008, 53, 993-1006. [CrossRef]

7. Dogan, U.; Cicek, I. Occurrence of cover-collapse sinkholes [cover-collapse dolines] in the May Dam reservoir area (Konya, Turkey). Cave Karst Sci. 2002, 29, 111-116.

8. Waltham, A.C.; Fookes, P.G. Engineering classification of karst ground conditions. Q. J. Eng. Geol. Hydrogeol. 2003, 36, 101-118. [CrossRef]

9. Gutie'rrez, F.; Cooper, A.H. Surface morphology of gypsum karst. In Treatise on Geomorphology; Shroder, J., Frumkin, A., Eds.; Academic Press: San Diego, CA, USA, 2013; Volume 6, pp. 425-437.

10. Khomenko, V.P.; Tolmachev, V.V. Sinkholes. In Encyclopedia of Engineering Geology. Encyclopedia of Earth Sciences Series; Bobrowsky, P.T., Marker, B., Eds.; Springer Cham: Copenhagen, Denmark, 2018. [CrossRef]

11. Veress, M. Covered Karst; Springer: Berlin/Heidelberg, Germany; New York, NY, USA, 2016; 536p. [CrossRef]

12. Amato, V.; Aucelli, P.P.C.; Cesarano, M.; Filocamo, F.; Leone, N.; Petrosino, P.; Rosskopf, C.M.; Valente, E.; Casciello, E.; Giralt, S.; et al. Geomorphic response to late Quaternary tectonics in the axial portion of the Southern Apennines (Italy): A case study from the Calore River valley. Earth Surf. Process. Landf. 2018, 43, 2463-2480. [CrossRef]

13. Pazzi, V.; di Filippo, M.; di Nezza, M.; Carlà, T.; Bardi, F.; Marini, F.; Fontanelli, K.; Intrieri, E.; Fanti, R. Integrated geophysical survey in a sinkhole-prone area: Microgravity, electrical resistivity tomographies, and seismic noise measurements to delimit its extension. Eng. Geol. 2018, 243, 282-293. [CrossRef]

14. Veress, M. Glaciális felszíntípusok karsztosodása (Karstification of glacial surface types). Földrajzi Közlemények 2013, 187, 2-27.

15. Waltham, T. Fengcong, fenglin, cone karst and tower karst. Cave Karst Sci. 2008, 35, 77-88.

16. Veress, M. Karst Types and Their Karstification. J. Earth Sci. 2020, 30, 621-634. [CrossRef]

17. Korzhuev, S.S. Merzlotnij karszt Szrednego Prilenja i nekotorije oszobennoszti jego projavlenija. In Regionalnoje Karsztovedenije; Sokolov, N.I., Gvozdetskiy, N.A., Balashov, L.S., Eds.; Izdatelsztvo AN SzSzSzR: Moscow, Russia, 1961; pp. $207-220$.

18. Upchurch, S.; Scott, T.M.; Alfieri, M.C.; Fratesi, B.; Dobecki, T.L. Epigene and Hypogene Karst-The Karst Systems of Florida; Springer: Copenhagen, Denmark, 2019; pp. 359-441.

19. Quinlan, J.F.; Smith, A.R.; Johnson, K.S. Gypsum karst and salt karst of the United States of America. Le Grotte D'Italia 1986, 4, 73-92.

20. Calligaris, C.; Zini, L.; Nisio, S.; Piano, C. Sinkholes in the Friuli Venezia Giulia Region Focus on the Evaporites. In Applied Geology; De Maio, M., Tiwari, A., Eds.; Springer: Copenhagen, Denmark, 2020; pp. 73-90. [CrossRef]

21. Cooper, A.H.; Waltham, A.C. Subsidence caused by gypsum dissolution at Ripon North Yorkshire. Q. J. Eng. Geol. 1999, 32, 305-310. [CrossRef]

22. Martinez, J.D.; Johnson, K.S.; Neal, J.T. Sinkholes in Evaporite Rocks. Am. Sci. 1998, 86, 38-51. [CrossRef]

23. Klimchouk, A.; Andrejchuk, V. Karst breakdown mechanisms from observations in the gypsum caves of the western Ukraine: Implications for subsidence hazard assessment. Environ. Earth Sci. 2003, 1, 20. Available online: www.speleogenesis.info (accessed on 2 January 2021).

24. Santo, A.; Ascione, A.; Prete, S.D.; Crescenzo, G.; Santangelo, N. Collapse Sinkholes Distribution in the Carbonate Massifs of Central and Southern Apennines. Acta Carsologica 2011, 40, 95-112.

25. Santo, A.; Budetta, P.; Forte, G.; Marino, E.; Pignalosa, A. Karst collapse susceptibility assessment: A case study on the Amalfi Coast (Southern Italy). Geomorphology 2017, 285, 247-259. [CrossRef]

26. Caramanna, G.; Ciotoli, G.; Nisio, S. A review of natural sinkhole phenomena in Italian plain areas. Nat. Hazards 2008, 45, 145-172. [CrossRef]

27. Parise, M. A procedure for evaluating the susceptibility to natural and anthropogenic sinkholes. Georisk Assess. Manag. Risk Eng. Syst. Geohazards 2015, 9, 272-285. [CrossRef]

28. Cui, Z.; Li, D.; Feng, J.; Liu, G.; Li, H. The covered karst, weathering crust and karst (double-level). Sci. China 2002, 45, 366-378.

29. Waltham, T.; Bell, F.; Culshaw, M. Sinkholes and Subsidence; Springer: Berlin/Heidelberg, Germany, 2005; 382p.

30. Pessoa, P. Karst Hydrogeology of the Lagoa Santa Area, in Lagoa Santa Karst Brazil's Iconic Karst Region; Springer: Copenhagen, Denmark, 2020; pp. 135-188. [CrossRef]

31. Jia, L.; Li, L.; Meng, Y.; Wu, Y.; Pan, Z.; Yin, R. Responses of cover-collapse sinkholes to groundwater changes: A case study of early warning of soil cave and sinkhole activity on Datansha Island in Guangzhou, China. Environ. Earth Sci. 2018, 77, 488. [CrossRef]

32. Williams, P.W. The role of the epikarst in karst and cave hydrogeology: A review. Int. J. Speleol. 2008, 37, 1-10. [CrossRef] 
33. He, K.; Liu, C.; Wang, S. Karst collapse related to over-pumping and a criterion for its stability. Environ. Geol. 2003, 43, 720-724. [CrossRef]

34. Chen, J.; Beck, B.F. Qualitative modelling of the cover-collapse process. In Engineering and Environmental Impacts of Sinkholes and Karst; Beck, B.F., Ed.; Balkema: Rotterdam, The Netherlands, 1989; pp. 89-95.

35. Santo, A.; Santangelo, N.; De Falco, M.; Forte, G.; Valente, E. Cover collapse sinkhole over a deep buried carbonate bedrock: The case study of Fossa San Vito (Sarno-Southern Italy). Geomorphology 2019, 345, 106838. [CrossRef]

36. Yuan, D. Environmental and engineering problems of karst geology in China. In Karst Hydrogeology: Engineering and Environmental Applications; Beck, B.F., Wilson, W.L., Eds.; Balkema: Rotterdam, The Netherlands, 1987; pp. 1-11.

37. Miranda, E.; Brzev, S.; Bijeli'c, N.; Arbanas, Ž.; Bartolac, M.; Jagodnik, V.; Lazarevi'c, D.; Mihali'c Arbanas, S.; Zlatovi'c, S.; Acosta, A.; et al. PRJ-2959/StEER-EERI: Petrinja, Croatia December 29, 2020, Mw 6.4 earthquake (PI: Kijewski-Correa, T.). Field Research, Joint Reconnaissance Report; DesignSafe: Seattle, WA, USA, 15 March 2021; p. 206.

38. Drumm, E.C.; Kane, W.F.; Yoon, C.J. Application of limit plasticity to the stability of sinkholes. Eng. Geol. 1990, 29, 213-225. [CrossRef]

39. Tharp, T.M. Mechanics of upward propagation of cover-collapse sinkholes. Eng. Geol. 1999, 52, 23-33. [CrossRef]

40. Veress, M.; Gárdonyi, I.; Deák, G. Fedett karsztosodás vizsgálata fedővel borított gipsztáblán (The study of covered karstification on a gypsum plate with cover). Karsztfejlödés 2014, 14, 159-171. (In Hungarian)

41. Currens, I.C.; Paylor, R.L.; Beck, F.G.; Davidson, B. A method to determine cover-Collapse frequency in the Western Pennyroyal karst of Kentucky. J. Cave Karst Stud. 2012, 74, 292-299. [CrossRef]

42. Xu, W.; Zhao, G. Mechanism and prevention of karst collapse near mine areas in China. Environ. Geol. Water Sci. 1988, 12, 37-42.

43. Wilson, W.L. Sinkhole and buried sinkhole densities and new sinkhole frequencies in karsts of northwest peninsular Florida. In Karst Geohazards; Beck, B.F., Ed.; Balkema: Rotterdam, The Netherlands, 1995; pp. 79-91.

44. Benson, R.C.; Kaufmann, R.D. Characterization of a highway sinkhole within the gypsum karst of Michigan. In Geotechnical and Environmental Applications of Karst Geology and Hydrology; Beck, B.F., Herring, J.G., Eds.; Balkema: Lisse, The Netherlands, 2001; pp. 103-112.

45. Benson, R.C.; Yuhr, L.B. Assessment and long term monitoring of localized subsidence using ground penetrating radar. In Karst Hydrogeology: Engineeering and Environmental Applications; Beck, B.F., Wilson, W.L., Eds.; Balkema: Rotterdam, The Netherlands, 1987; pp. 161-169.

46. Veress, M. Investigation of covered karst form development using geophysical measurements. Z. Für Geomorph. 2009, 53, 469-486. [CrossRef]

47. Veress, M. The Evolution and Development of Solution Dolines with Horizontal Growth and the Processes of Their Floors: A Case Study on the Plate-Shaped Dolines of the Bükk Mountains, Aggtelek Karst and Pádis Plataeu. Earth 2020, 1, 47-74. [CrossRef]

48. Crawford, N.C. Environmental problems associated with urban development upon karst, Bowling Green, Kentucky. In Geotechnical and Environmental Applications of Karst Geology and Hydrology; Beck, B.F., Herring, J.G., Eds.; Balkema: Lisse, The Netherlands, 2001; pp. 397-424.

49. Jakucs, L. Morphogenetics of Karst Regions; Adam Hilgar: Bristol, UK, 1977; 284p.

50. Bulla, B. Morfológiai megfigyelések a magyarországi löszös területeken (Morphological observations on Hungarian loess areas). Földrajzi Közlemények 1933, 61, 136-149. (In Hungarian)

51. White, W.B. Geomorphology and Hydrology of Karst Terrains; Oxford University Press: New York, NY, USA; Oxford, UK, 1988.

52. Halliday, W.R. Piping Caves and Badlands Pseudokarst. In Encyclopedia of Caves and Karst Science; Gunn, J., Ed.; Fritzroy Dearban: New York, NY, USA, 2004; pp. 589-593.

53. Halliday, W.R. Pseudokarst. In Encyclopedia of Caves and Karst Science; Gunn, J., Ed.; Fritzroy Dearban: New York, NY, USA, 2004; pp. 604-608.

54. Veress, M. Covered Karst Evolution Northern Bakony Mountains, W-Hungary; A Bakony Természettud. Kut. Eredményei, 23; Bakonyi Természettudományi Múzeum: Zirc, Hungary, 2000; 167p.

55. Veress, M. Adatok a Hárskúti-fennsík karsztmorfogenetikájához. (Data on the morphogenesis of the Hárskút Plateau). In Karszt és Barlang; Lénárt, L., Eszterhás, I., Cholnoky, J., Eds.; Hungarian Karst and Cave Research Society: Budapest, Hungary, 1982; Volume II, pp. 71-82. (In Hungarian)

56. Trudgill, S.T. The influence of drifts and soils on limestone weathering in N.W. Claire, Ireland. Proc. Univ. Bristol. Speleol. Soc. 1972, 13, 113-118.

57. Trudgill, S.T. Limestone Geomorphology; Longman: New York, NY, USA, 1985; 196p.

58. Beck, B.F.; Sinclair, W.C. Sinkholes in Florida: An Introduction; Florida Sinkhole Research Institute Report; Florida Sinkhole Research Institute: Orlando, FL, USA, 1986; Volume 85-86-4, 16p.

59. Beck, B.F. On calculating the risk of sinkhole collapse. In Proceedings of the Appalochian Karst Symposium, Radford, VA, USA, 23-26 March 1991; National Speleological Society Huntsville: Huntsville, AL, USA, 1991; pp. 231-236.

60. Ketelle, R.H.; Newton, J.G.; Tanner, J.M. Karst subsidence in East Tennessee. In Proceedings of the 2nd Conference on Environmental Problems in Karst Terranes and Their Solution, Bowling Green, KY, USA, 28-30 October 1986; National Water Well Association: Dublin, OH, USA, 1988; pp. 51-65.

61. Hoyk, E. A Nyugat-Mecsek karszt dolináinak morfometriai vizsgálata (A morphometric investigation of the karst dolines of Western Mecsek). Karsztfejlödés 2002, 7, 161-171. (In Hungarian) 
62. Mezősi, G. Magyarország természetföldrajza (Physical Geography of Hungary); Akadémia Kiadó: Budapest, Hungary, 2011; 393p. (In Hungarian)

63. Veress, M.; Vetési-Foith, S. The Distribution of Surface Karst Features in the Bakony Region (Transdanubian Mountains Hungary). J. Geol. Res. 2019, 1, 21-25. [CrossRef]

64. Lippmann, L.; Kiss, K.; Móga, J. Az Abaliget-Orfúi karszt karsztos felszínformáinak vizsgálata térinformatikai módszerekkel (Investigation of the karstic phenomenon near Orfú and Abaliget by GIS methods). Karsztfejlödés 2008, 13, 151-166. (In Hungarian)

65. Vetési-Foith, S. A Mecseki karszt oldódásos és utánsüllyedéses töbreinek morfometriai elemzése (Morphometric analysis of dissolved- and subsidence dolines in the Mecsek Karst). Karsztfejlödés 2017, 22, 119-138. (In Hungarian) [CrossRef]

66. Hevesi, A. A Nyugat-Mecsek felszíni karsztosodásának kérdései (Questions of the surface karstification of the West Mecsek). Karsztfejlödés 2011, 7, 103-111. (In Hungarian)

67. Veress, M. Északi-Bakony fedett karsztja (Covered karst of the Northern Bakony); Bakonyi Természettudományi Múzeum: Zirc, Hungary, 1999; 167p. (In Hungarian)

68. Soriano, M.A.; Simón, J.L. Subsidence rates of alluvial dolines in the central Ebro basin, Northeastern Spain. In Geotechnical and Environmental Applications of Karst Geology and Hydrology; Beck, B.F., Herring, J.G., Eds.; Balkema: Lisse, The Netherlands, 2001; pp. $47-52$.

69. Williams, P.W. Illustrating morphometric analysis of karst with examples from New Guinea. Z. Für Geomorphol. 1971, 15, 40-61.

70. Vetési-Foith, S. Az utánsüllyedéses dolinák képződését befolyásoló paraméterek kapcsolatrendszerének vizsgálata modell kísérlettel (Analysing the relation of the parameters that influences the subsidence dolines formation using model experiments). Karsztfejlödés 2019, 24, 61-78. (In Hungarian) [CrossRef]

71. Cramer, H.C. Die Systematik der Karstdolinen. N. Jb. Miner. Geol. Paläont. 1941, 85, $293-382$.

72. Clayton, K.M. The origin of the landforms of the Malham area. Field Stud. 1966, 2, 359-384.

73. Beck, B.F. A generalized genetic framework for the development of sinkholes and karst in Florida, USA. Environ. Geol. Water Sci. 1986, 8, 5-18. [CrossRef]

74. Lu, Y.; Cooper, A.H. Gypsum karst geohazards in China. In Engineering Geology and Hydrogeology of Karst Terrains; Beck, B.F., Stephenson, J.B., Eds.; Balkema: Rotterdam, The Netherlands, 1997; pp. 117-126.

75. Hevesi, A. Adatok a Bükk hegység negyedidőszaki ősföldrajzi képéhez (Data to the Quaternary Paleogeographical Features of the Bükk Mountains). Földtani Közlöny 1980, 110, 540-550. (In Hungarian)

76. Veress, M. Shaft Lengths and Shaft Development Types in the Vadose Zone of the Bakony Region (Transdanubian Mountains, Hungary). J. Soil Water Sci. 2019, 3, 54-74. Available online: ojs.bilpublishing.com/index.php/jgr-a (accessed on 2 January 2021).

77. Hyatt, J.A.; Wilson, R.; Givens, J.S.; Jacobs, P.M. Topographic, geologic and hydrogeologic controls on dimension and locations of sinkholes in thick covered karst, Lowndes Country, Georgia. In Geotechnical and Environmental Applications of Karst Geology and Hydrology; Beck, B.F., Herring, J.G., Eds.; Balkema: Lisse, The Netherlands, 2001; pp. 37-45.

78. Lei, M.; Jiang, X.; Yu, L. New advances of karst collapse research in China. In Geology and Hydrology; Beck, B.F., Ed.; Balkema: Lisse, The Netherlands, 2001; pp. 145-151.

79. Chen, J. Karst collapses in cities and mining areas, China. Environ. Geol. Water Sci. 1988, 12, 29-35. [CrossRef]

80. Beggs, T.F.; Ruth, B.E. Factors affecting the collapse of cavities. In Sinkholes: Their Geology, Engineering and Environmental Impact; Beck, B.F., Ed.; Balkema: Rotterdam, The Netherlands, 1984; pp. 183-188.

81. Upchurch, S.B.; Littlefield, J.R. Evalutions of data for sinkhole-development risk models. In Karst Hydrogeology: Engineering and Environmental Applications; Beck, B.F., Wilson, W.L., Eds.; Balkema: Rotterdam, The Netherlands, 1987; pp. 359-364.

82. Xiang, S.; Chen, J.; Wilson, W.L.; Beck, B.F. Sinkholes as a consequence of groundwater development in karst regions. Am. Inst. Hydrol. J. 1988, 4, 160-173.

83. Silvestru, E. Dolines in the Padiş Plateau (Bihor Mountains, Romania), One peculiar case, many questions. Theor. Appl. Karstology 1997, 10, 127-132.

84. Arrington, D.V.; Lindquist, R.C. Thickly mantled karst of the Interlachen, Florida area. In Karst Hydrogeology: Engineering and Environmental Applications; Beck, B.F., Wilson, W.L., Eds.; Balkema: Rotterdam, The Netherlands, 1987; pp. 31-39.

85. Beck, B.F. Report on Italian sinkhole conference. KWI Conduit 2000, 8. Available online: www.karstwaters.org (accessed on 2 January 2021).

86. Deák, G.; Szemes, M.; Veress, M. A gipsz fedőjének vízmozgásai fizikai analóg modelleken (Water movements of the plaster cover on physical analogue models). Karsztfejlődés 2015, 20, 215-229. (In Hungarian) [CrossRef]

87. Stefanovits, P. Talajtan (Soil Science); Mezőgazdasági Kiadó: Budapest, Hungary, 1981; 470p. (In Hungarian)

88. Veress, M.; Gárdonyi, I.; Deák, G. Gipsz hasadékkarrjainak vizsgálata modellkísérletekkel (The study of grikes of plaster with model experiments). Karsztfejlódés 2015, 20, 231-250. (In Hungarian) [CrossRef]

89. Zámbó, L. A vörösagyagok és a felszíni karsztosodás kapcsolata az Aggteleki-karszt délnyugati részén (The relationship between red clays and surface karstification at the southwestern part of Aggtelek Karst). Földrajzi Közlemények 1970, 94, 281-293. (In Hungarian)

90. Zámbó, L. Karsztvörösagyagok $\mathrm{CO}_{2}$ termelés és a karsztkorrózió összefüggése (The connection between the $\mathrm{CO}_{2}$ production of karst red clays and karst corrosion). A Nehézipari Müszaki Egy. Közleményei I. Sor. Bányászat 1986, 33, 125-138. (In Hungarian)

91. Williams, P.W. Limestone pavements with special reference to western Ireland. Trans. Inst. Br. Geogr. 1966, 40, 155-172. [CrossRef] 
92. Balázs, D. Kísérletek a talaj alatti karsztos korrózióról (Experiments on subsoil karst corrosion). Karszt És Barlang 1969, 2, 57-60. (In Hungarian)

93. Trudgill, S.T. Measurement of erosional weight-loss of rock tables. British Geomorphological Research Group. Tech. Bull. 1975, $17,13-19$.

94. Trudgill, S.T. Limestone erosion under soil. In Proceedings of the 6th International Congress of Speleology, Olomouc, Czechoslovakia, 9 September 1973; Panos, V., Ed.; Academia: Prague, Checz Republic, 1976; pp. 409-422.

95. Trudgill, S.T. The erosion of limestones under soil and long term stability of soil-Vegetation systems on limestone. Earth Surf. Process. 1976, 1, 31-41. [CrossRef]

96. Kiss, K.; Zámbó, L.; Fehér, K.; Móga, J. A lösztakaró karsztosodásban játszott szerepének vizsgálata a Tési-fennsíkon (An investigation of the role of the loess mantle in karstification on the Tés Plateau). Karsztfejlödés 2007, 12, 193-205. (In Hungarian)

97. Füzesi, I. Loess tests carried out in the surroundings of some covered karstic depressions (Tési-Plateau). Carpathian J. Earth Environ. Sci. 2007, 2, 39-44.

98. Sinkholes. 20 August 2020. Available online: http://www.dep.state.flius/geology/geologictopics/sinkhole.htm (accessed on 2 January 2021).

99. Hyatt, J.A.; Jacobs, P.M. Distribution and morphology of sinkholes triggered by flooding Tropical Storm Alberto at Albany, Georgia, USA. Geomorphology 1996, 17, 305-316. [CrossRef]

100. Jammal, S.E. Maturation of the Winter Park sinkhole. In Sinkholes: Their Geology, Engineering and Environmental Impact; Beck, B.F., Ed.; Balkema: Rotterdam, The Netherlands, 1984; pp. 363-369.

101. Sweeting, M.M. Karst in China: Its Geomorphology and Environment; Springer: Berlin, Germany, 1995 ; p. 265.

102. Foose, R.M. Surface subsidence and collapse caused by ground water withdrawal in carbonate rock areas. In Proceedings of the 23rd International Geological Congress, Prague, Czech Republic, 6 June 1968; Academia: Prague, Czech Republic, 1968; Volume 12, pp. 155-166.

103. LaMoreaux, P.E.; Newton, J.G. Catastrophic subsidence: An environmental hazard, Shelby County, Alabama. Environ. Geol. Water Sci. 1986, 8, 25-40. [CrossRef]

104. Waltham, A.C.; Smart, P.L. Civil engineering difficulties in the karst of China. Q. J. Eng. Geol. 1988, 21, 2-6. [CrossRef]

105. Foose, R.M. Groundwater behaviour in the Hershey Valley. Penn. Bull. Geol. Soc. Am. 1953, 54, 623-645. [CrossRef]

106. Brassington, R. Field Hydrogeology; Geological Society of London, Professional Handbook Series; Open University Press: Maidenhead, UK, 1988.

107. Mádl Szőnyi, J.; Czaune, B.; Simon, S.; Erőss, A.; Zsemle, F.; Pulay, E.; Havril, T. Hidrogeológia, Digitális Tankönyv ELTE; Hydrogeology, Digital Book; ELTE: Budapest, Hungary, 2013. (In Hungarian)

108. Jefferies, M.; Been, K. Soil Liquefaction: A Critical State Approach, 1st ed.; CRC Press: Boca Raton, FL, USA, 2006. [CrossRef]

109. Cvijič, J. Hydrographie souterraine et evolution morphologique du karst. Rev. De Géographie Alp. 1918, 6, 375-426. [CrossRef]

110. Cholnoky, J. A csillagoktól a tenger fenékig (From the Stars to the Sea Bottom); Franklin Társulat: Budapest, Hungary, $1940 ;$ p. 496. (In Hungarian)

111. Gams, I. The polje: The problem of its definition. Z. Für Geomorphol. 1978, 22, 170-181.

112. Beese, A.P.; Creed, M.J. A database for subsidence sinkholes near Cork, Ireland. Dan. Geotech. Soc. Bull. 1995, 4, 19-24.

113. Czerniawska, J.; Chlachula, J. Climate-change induced permafrost degradation in Yakutia. Arctic 2020, 73, 509-528. [CrossRef]

114. Likens, G.E. River Ecosystem Ecology: A Global Perspective; Academic Press: San Diego, CA, USA, 2010; 424p.

115. Rowley, T.; Giardino, R.; Granados Aguilar, R.; Vitek, J.D. Periglacial processes and landforms in the critical zona. Dev. Earth Surf. Process. 2015, 19, 397-447.

116. Van Everdingen, R.O. Morphology, Hydrology and Hydrochemistry of Karst in Permafrost Near Great Bear Lake, Northwest Territories; Paper 11; National Hydrological Research Institute of Canada: Saskatoon, SK, Canada, 1981.

117. Pollard, W.; Omelon, C.; Andersen, D.; McKay, C. Perennial spring occurrence in the Expedition Fiord area of western Axel Heiberg Island, Canadian High Arctic. Can. J. Earth Sci. 1999, 36, 105-120. [CrossRef]

118. Lungersgauzen, G.F. Inflyuviy-osobyi geneticheskiy tip materikovykh obrazovaniy. Dokl. Akad. Nauk. SSSR 1966, 171,690-693.

119. Korzhuev, S.S. Drevniy karst i tsikly karstoobrazovaniya Sibirskoy platformy. Tr. Mosk. Obs. Ispyt. Prir. 1972, 47, $141-151$.

120. Pulina, M. Le karst et les phenomenes karstiques similaires des regions froides. In Les Karsts des Regions Climatiques Extremes; Salomon, J.N., Pulina, M., Eds.; Presses Universitaires de Bordeaux: Pessac, France, 2005; Volume 14, pp. 11-100.

121. Parise, M. Recognition of instability features in artificial cavities. In Proceedings of the 16th International Congress of Speleology, Brno, Czech Republic, 21-28 July 2013; p. 28.

122. Fazio, N.L.; Perrotti, M.; Lollino, P.; Parise, M.; Vattano, M.; Madonia, G.; Di Maggio, C. A three-dimensional back-analysis of the collapse of an underground cavity in soft rocks. Eng. Geol. 2017, 228, 301-311. [CrossRef]

123. De Waele, J.; Piccini, L.; Columbu, A.; Madonia, G.; Vattano, M.; Calligaris, C.; D’Angeli, I.; Parise, M.; Chiesi, M.; Sivelli, M.; et al Evaporite karst in Italy: A review. Int. J. Speleol. 2017, 46, 137-168. Available online: https://digitalcommons.usf.edu/ijs/vol46/ iss $2 / 3$ (accessed on 2 January 2021). [CrossRef]

124. Cucchi, F.; Forti, P.; Finocchiaro, F. Gypsum degradation in Italy with respect to climatic textural and erosional conditions. Geogr. Fis. E Din. Quat. 1998, 3, 41-49.

125. Parise, M.I. Sinkholes in Puglia. Mem. Descr. Della Carta Geol. D'italia 2008, 85, 309-334. 
126. Fidelibus, M.D.; Gutiérrez, F.; Spilotro, G. Human-induced hydrogeological changes and sinkholes in the coastal gypsum karst of Lesina Marina area (Foggia Province, Italy). Eng. Geol. 2011, 118, 1-19.

127. Di Maggio, C.; Di Trapani, F.P.; Madonia, G.; Salvo, D.; Vattano, M. Primo contributo sui sinkhole nelle evaporiti della Sicilia (Italia)/First report on the sinkhole phenomena in the Sicilian evaporites (Italy). In Proceedings of the 2 Workshop Internazionale. I Sinkholes. Gli Sprofondamenti Catastrofici Nell'Ambiente Naturale ed in Quello Antropizzato, Roma, Italy, 3-4 December 2009; ISPRA: Rome, Italy, 2010; pp. 299-313.

128. Johnson, K.S. Development of the Wink Sink in West Texas due to salt dissolution and collapse. In Karst Hydrogeology: Engineering and Environmental Implication; Beck, B.F., Wilson, W.L., Eds.; Balkema: Brookfield, VT, USA; CRC Press: Boca Raton, FL, USA, 1987; pp. 127-136.

129. Johnson, K.S.; Collins, E.W.; Seni, S.J. Sinkholes and land subsidence due to salt dissolution near Wink, West Texas, and other sites in western Texas and New Mexico. Okla. Geol. Surv. Circ. 2003, 109, 183-195.

130. Guo, X. Geological Hazards of China and their Prevention and Control; Geological Publishing House: Beijing, China, 1991; 260p.

131. Johnson, K.S. Land subsidence above man-made salt dissolution cavities. In Land Subsidence Case Studies and Current Research: Proceedings of the Dr. Joseph F. Poland Symposium on Land Subsidence; Assoc. Eng. Geol. Spec. Publ., Borchers, J.W., Eds.; Star Publishing Co.: Belmont, CA, USA, 1998; Volume 8, pp. 385-392.

132. Vigna, B.; Fiorucci, A.; Banzato, C.; Forti, P.; De Waele, J. Hypogene gypsum karst and sinkhole formation at Moncalvo (Asti, Italy). Z. Für Geomorphol. 2010, 54, 285-306. [CrossRef]

133. Sowers, G.F. Building on Sinkholes; ASCE Press: New York, NY, USA, 1996; 202p.

134. Li, J.; Niu, J.; Liu, Q.; Li, G. Subsidence and its treatment in karst coal mines in China. In Proceedings of the 11th International Congress Speleology, Beijing, China, 2-8 August 1993; pp. 180-181.

135. Dogan, U.; Yilmaz, M. Natural and induced sinkholes of the Obruk Plateau and Karapinar-Hotamis Plain, Turkey. J. Asian Earth Sci. 2011, 40, 496-508. [CrossRef]

136. Sütő, L.; Homoki, E.; Németh, G. Felszínsüllyedési és Bolygatottsági térkép KészítéSe a Kelet-Borsodi-Szénmedencében (Construction of a Subsidence and Disturbance Map in the East Borsod Coal Basin). In Proceedings of the Geoinformatika és domborzatmodellezés, HunDEM 2009 és GeoInfo konferencia és kerekasztal válogatott tanulmánya, Budapest, Hungary; 2009. Available online: https:/ / docplayer.hu/8279580-Terinformatikai-adatbazis-es-terkepei-az-antropogen-hatasok-kutatasabana-kelet-borsodi-szenmedenceben.html (accessed on 2 January 2021). (In Hungarian).

137. Wassmann, T.H. Mining subsidence in Twente East Netherlands. Geol. Mijnbouw 1980, 59, $225-231$.

138. Andrejchuk, V. Collapse above the World's largest Potash Mine (Ural, Russia). Int. J. Speleol. 2002, 31, 137-158. [CrossRef]

139. Móga, J.; Lippmann, L.; Tombor, E.; Fehér, K.; Kéri, A.; Borsodi, A. Az Aknaszlatinai sókarszt felszínalaktani vizsgálata (Geomorphological investigation of the Aknaszlatina saltkarst (Ukrajna)). Karsztfejlödés 2015, 20, 185-283. (In Hungarian) [CrossRef]

140. Móga, J.; Szabó, J.; Gönczy, S.; Lippmann, L.; Bódai, B. Az Aknaszlatinai-sókarszt dinamikusan változó felszínformáinak vizsgálata terepi és GIS módszerekkel (The study of the dynamically changing landforms of Aknaszlatina salt karst by field and GIS methods). Karsztfejlődés 2017, 22, 139-161. (In Hungarian) [CrossRef]

141. Walters, R.F. Land subsidence in central Kansas related to salt dissolution. Bull. Kans. Geol. Surv. 1977, $214,74-75$.

142. Wassmann, T.H. Mining subsidence in the East Netherlands. In Evaluation and Prediction of Subsidence; Saxena, S.K., Ed.; American Society Civil Engineers: New York, NY, USA, 1979; pp. 283-302.

143. Spooner, J. Mufulira interim report. Min. J. 1971, 276, 122.

144. Singh Kalendra, B. Sinkhole subsidence due to mining. Geotech. Geol. Eng. 1997, 15, 327-341. [CrossRef] 